NBER WORKING PAPER SERIES

EXCHANGE RATE POLICY RECONSIDERED

Richard C. Marston

Working Paper No. 2310

NATIONAL BUREAU OF ECONOMIC RESEARCH

1050 Massachusetts Avenue

Cambridge, MA 02138

July 1987

Presented at the Conference on International Economic Cooperation, April 1987. Support from the Ford Foundation project on International Coordination of Economic Policy is gratefully acknowledged. The research reported here is part of the NBER's research program in International Studies. Any opinions expressed are those of the author and not those of the National Bureau of Economic Research. 
NBER Working Paper \#2310

July 1987

\section{Exchange Rate Policy Reconsidered}

\section{ABSTRACT}

The Bretton Woods Conference of 1944 which fixed exchange rates for over twenty-five years is often cited as a model of economic cooperation among countries. Yet over fifteen years have elapsed since the breakdown of the Bretton Woods System without any serious efforts to restore fixed exchange rates among the currencies of the major industrial countries. This paper considers why governments may have refrained from "reforming" the exchange rate system.

The first section of the paper examines the principal problem which exchange rate policy is designed to address, exchange rate variability. The paper distinguishes between the short run volatility of exchange rates, which firms can hedge against in the financial markets, and longer term swings in real exchange rates, which can lead to costly resource reallocation.

The paper reviews evidence concerning the effectiveness of exchange market intervention, evidence which suggests that intervention may not be effective unless it is monetized. The paper goes on to analyze arguments concerning fixed exchange rates, and to assess the experience of two fixed rate systems, Bretton Woods and the European Monetary System. Finally, the paper examines the target zone system which has been proposed as an alternative to freely floating and fixed exchange rates.

Richard C. Marston The Wharton School 2300 Steinberg-Dietrich Hall University of Pennsylvania Philadelphia, PA 19104 Telephone: 215-898-7626 
I would regard it as a catastrophe amounting to a world tragedy if [this Conference should]. . . allow itself to be diverted by the proposal of a purely artificial and temporary experiment affecting the monetary exchange of a few nations only. . . . The sound internal economic system of a nation is a greater factor in its well being than the price of its currency in changing terms of the currencies of other nations [from President Franklin D. Roosevelt's message to the London Economic Conference of 1933].

It has been our task to find a common measure, a common standard, a common rule applicable to each and not irksome to any. . . [ [W] have perhaps accomplished here in Bretton Woods something more than what is embodied in this Final Act. We have shown that a concourse of 44 nations are actually able to work together at a constructive task in amity and unbroken accord [J.M. Keynes, at the conclusion of the Bretton Woods Conference in 1944].

The Bretton Woods Conference of 1944 which fixed exchange rates for over twenty-five years is often cited as a model of economic cooperation among countries. Indeed the Bretton Woods Agreement on exchange rates was a remarkable accomplishment, particularly when measured against the failures of earlier conferences such as the London Economic Conference of 1933. Yet over fifteen years have elapsed since the breakdown of the Bretton Woods System without any serious efforts to restore fixed exchange rates among the currencies of the major industrial countries. The last attempt to reconstruct the exchange rate system, the Smithsonian Agreement of December 1971, broke down almost immediately. Recent economic summits have agreed on ad hoc policies to counter exchange rate movements and have considered modest proposals to modify the existing system, but these summits have made no progress on more systemic changes in exchange rate arrangements. Governments may have refrained from "reforming" the system for good reasons. This paper will consider arguments for and against more far-reaching international agreements on exchange rate policy. 
When considering possible reforms of the exchange rate system, it is natural to compare experience since 1973 with that of the Bretton Woods period. The difference in economic performance between the two periods would be startling if it were not so well known. Table 1 updates a table presented in Goldstein (1984, p. 10) that compares recent inflation rates, growth rates, and other economic variables with those of the Bretton Woods period. The period since 1973 is divided in two parts to highlight more recent developments in the 1980s.

Regardless of which indicator is chosen, the decade of the 1960s was a time of much superior economic performance. During the 1960s, inflation was markedly lower in all major industrial countries, with the notable exception of Japan where inflation in the 1980s is half what it was in the 1960s. A more recent trend toward lower inflation rates, however, is observed by comparing the 1981-85 and 1973-80 periods. Figure 1, illustrating the annual inflation rates for the three largest industrial economies, confirms this downward trend and also suggests that inflation rates for these countries may be converging. But these recent favorable trends in inflation are not matched by similar trends in output and other variables. Real growth in GNP was higher during the 1960 s in all countries. Productivity growth was higher in all countries during the 1960s than during the 1973-85 period as a whole, although in the United States and United Kingdom productivity growth during the 1980s has exceeded that of the 1960s. ${ }^{2}$ Finally, unemployment rates were in an entirely different range during the 1960s. In Germany, for example, unemployment averaged only $0.8 \%$ in the 1960 s, but $2.9 \%$ in the 1970 s and a depressingly high $7.1 \%$ in the 1980s. In the United Kingdom, a $2.6 \%$ unemployment rate during the 1960 s has turned into an $11.9 \%$ rate in the 
TABLE 1

COMPARISON OF MACROECONOMIC PERFORMANCE

IN THREE RECENT PERIODS

AVERAGE

U.S. CANADA JAPAN FRANCE GERMANY ITALY U.K.

INFLATION RATES:

$1961-71$

2.8

2.7

5.6

4.1

2.8

3.9

4.4

$1973-80$

8.5

8.7

$9.5 \quad 10.1$

4.9

$14.9 \quad 14.0$

$1981-85$

5.3

7.2

2.7

9.1

3.8

12.9

6.9

AVERAGE GNP

GROWTH RATES:

$1961-71$

$1973-80$

$1981-85^{*}$ $\begin{array}{lll}3.6 & 5.2 & 10.4\end{array}$

2.5

3.4

4.1

2.4

2.2

3.8

AVERAGE

PRODUCTIVITY GROWTH:

$1961-71$

2.9

4.5

9.8

6.4

5.5

6.5

3.8

1973-80

$1.6 \quad 2.1$

6.1

4.6

4.0

4.6

1.8

$1981-85$

3.7

2.4

5.3

4.5

3.9

3.5

5.0

AVERAGE

UNEMPLOYMENT RATES:

1961-71

1973-80

$1981-85$

*Until 1984 for Italy

SOURCES: CPI indexes and GNP from IMF, International Financial Statistics; productivity from U.S. Bureau of Labor Statistics; unemployment rates from OECD, Labor Force Statistics. 


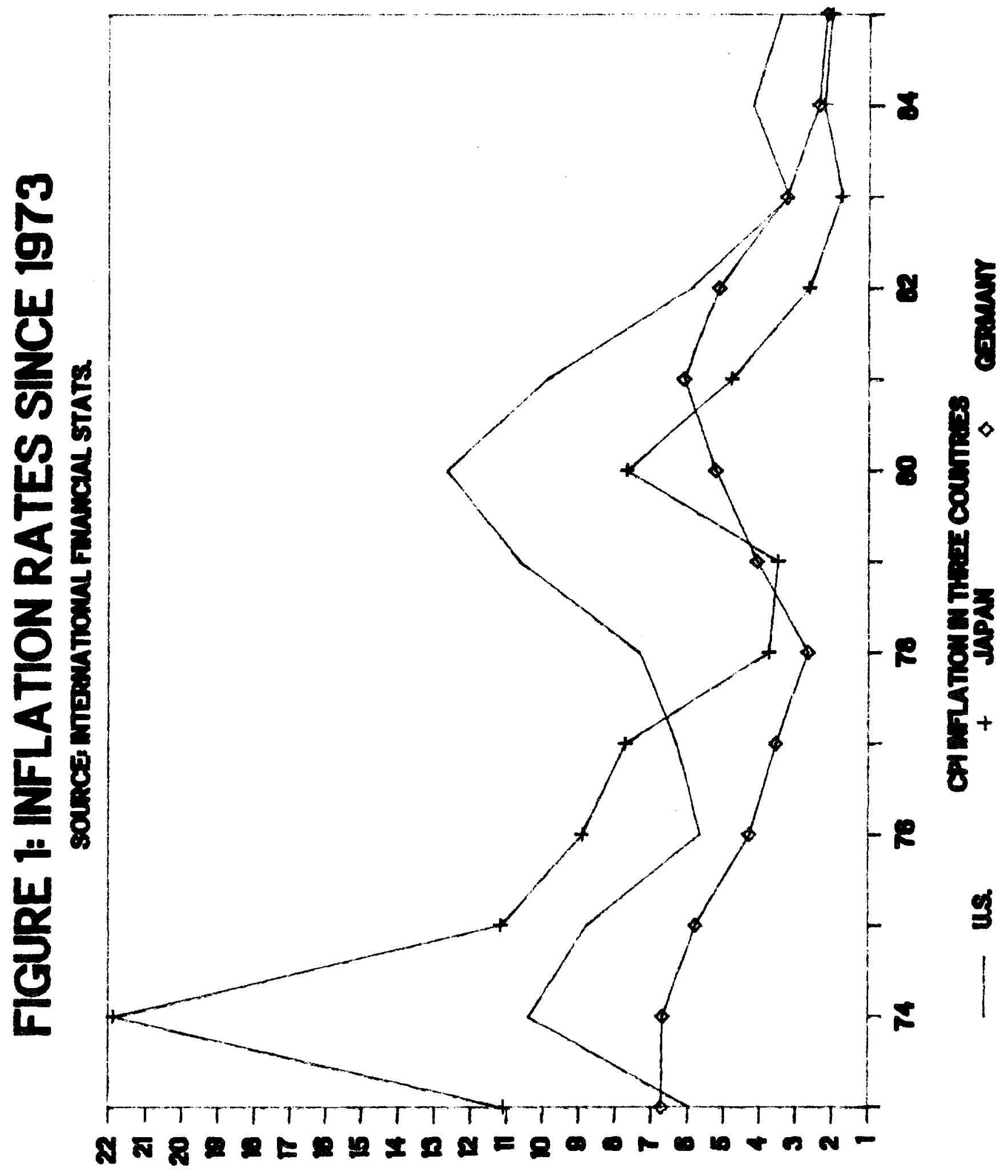

mons $/ x$ 
1980s. Compared with the recent period of flexible exchange rates, therefore, the 1960s appear to have been a golden era of economic performance.

Yet we should hesitate before attributing recent economic performance to the switch from fixed to flexible exchange rates. Although flexible rates may help to explain high inflation rates in the 1970s, it is much more difficult to tie growth rates, unemployment rates, or productivity performance to a nominal variable like the exchange rate. Nor is it easy to say how the fixed rate system would have performed in response to the economic disturbances of the $70 \mathrm{~s}$ and $80 \mathrm{~s}$, including the two oil shocks and the sharp changes in macroeconomic policies undertaken in Britain and the United States. Rather than try to account for this gap in economic performance, or to speculate about how a different exchange rate system might have performed, the paper will focus on the choices that are presented to policy-makers today. One of these choices is to return to fixed exchange rates, but in today's economic environment this may prove as difficult as putting Humpty Dumpty together again.

The paper addresses a number of issues important to exchange rate policy: Exchange Rate Variability: The first section of the paper examines the problem which exchange rate policy is designed to address, exchange rate variability. It distinguishes between two types of exchange rate variability, the short-run volatility of exchange rates characteristic of all asset prices and the misalignment of exchange rates which may persist for several years at a time. This distinction is crucial to an understanding of exchange rate policy, since actions designed to reduce volatility may not be well suited to countering misalignments.

Role of Sterilized Intervention: Casual observers may regard exchange market intervention as the primary tool of exchange rate policy, yet existing

27.18 .2 
evidence raises doubts about the effectiveness of intervention unaccompanied by changes in money supplies. The second section of the paper reviews existing statistical evidence on so-called sterilized intervention, then studies two recent episodes of foreign exchange intervention in November 1978 and September 1985.

Fixed Exchange Rates: Those who look on the Bretton Woods System with nostalgia may not recall how that system actually performed in practice. The third section examines arguments for and against fixed exchange rates in general. It then reviews experience under the Bretton Woods System as well as the recently established European Monetary System.

Rules for Managed Floating: The fourth section considers various proposals for managing exchange rates, including the rules adopted by the International Monetary Fund in 1978. One ambitious scheme for exchange rate management involves establishing target zones for the major currencies. The fourth section examines target zones in detail because of the attention given to targets in recent government and academic discussions.

\section{The Problem of Exchange Rate Variability}

Variable exchange rates pose problems for an economy, but the problems vary widely depending upon the nature of the variability. A useful distinction can be drawn between two types of variability, volatility and misalignment. Volatility is the day-to-day, month-to-month variability of exchange rates, a variability that may have no trend to it. Misalignment, in contrast, is the persistent departure of an exchange rate from its long run competitive level. Misalignment thus refers not to month-to-month variability but to longer-lasting movements of exchange rates, and only to those movements which depart from relative price trends, thus altering the relative competitiveness of a country's goods. 3 This distinction is important for 
intervention policy because a case might be made that only one form of variability is harmful and therefore might justify intervention. It must be admitted at the outset, however, that this distinction between the two forms of exchange rate variability is more easily made in theory than in practice, since exchange rates may exhibit their greatest volatility during periods of misalignment. Nonetheless, the paper will consider each form of variability in turn.

\subsection{Volatility}

One of the lessons learned from the voluminous literature on exchange rate behavior written in the 1970 s is that exchange rates behave like asset prices, displaying much more volatility than most macroeconomic variables such as output or the prices of goods and services. 4 This is not surprising given the dominance of asset trades in the determination of exchange rates. Table 2 examines the volatility of exchange rates using one measure of volatility, the standard deviation of monthly percentage changes in exchange rates. ${ }^{5}$ This measure of volatility, suggested by Lanyi and Suss (1982), counts as variable only those movements in exchange rates which depart from an average trend (measured as a percentage change).

\section{Volatility Comparisons}

Table 2 compares the volatility of exchange rates with the volatility of price ratios based on two aggregate price indexes, the consumer price index and the wholesale price index, for the so-called Group of Five industrial countries, France, Germany, Japan, United Kingdom and United States. According to this table, bilateral exchange rates are more than twice as volatile as these price ratios, in some cases more than five times as volatile. 6 This should not be surprising once it is recognized that, unlike 
TABLE 2

\section{STANDARD DEVIATIONS OF MONTHLY PERCENTAGE CHANGES \\ IN EXCHANGE RATES AND OTHER PRICES, JULY 1973-DECEMBER 1985}

EXCHANGE RATES:

\begin{tabular}{|c|c|c|c|}
\hline $\begin{array}{l}\text { UNITED } \\
\text { STATES }\end{array}$ & JAPAN & FRANCE & GERMANY \\
\hline
\end{tabular}

NOMINAL BILATERAL ${ }^{a}$

REAL BILATERAL $a, b$

NOMINAL EFFECTIVE ${ }^{\mathrm{C}}$

REAL EFFECTIVE ${ }^{b}, c$
0.0274

0.0256

0.0166

0.0229

0.0176
0.0279

0.0288

0.0272

0.0302

0.0120

0.0113

0.0116

0.0118

0.0197

PRICES :

\begin{tabular}{|c|c|c|c|c|c|}
\hline RATIOS OF CPI'Sa & & 0.0094 & 0.0037 & 0.0039 & 0.0081 \\
\hline RATIOS OF WPI'Sa & & 0.0106 & 0.0123 & 0.0078 & 0.0090 \\
\hline STOCK INDEXES & 0.0388 & 0.0294 & 0.0580 & 0.0315 & 0.0597 \\
\hline COMMODITY PRICES & $\begin{array}{l}\text { COPPER } \\
0.0481\end{array}$ & $\begin{array}{l}\text { COTTON } \\
0.0656\end{array}$ & $\begin{array}{c}\text { RICE } \\
0.0700\end{array}$ & $\begin{array}{c}\text { TIN } \\
0.0546\end{array}$ & $\begin{array}{l}\text { WHEAT } \\
0.0646\end{array}$ \\
\hline
\end{tabular}

NOTES:

$a_{A l l}$ bilateral comparisons are vis-a-vis the United States.

${ }^{b}$ Real exchange rates are measured using wholesale price indexes.

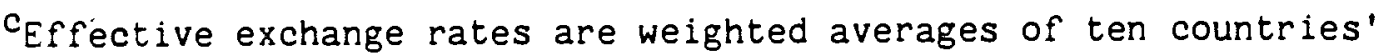
exchange rates ( $G-5$ plus Belgium, Canada, Italy, the Netherlands, and Switzerland); weights are based on total trade (imports plus exports) in manufactures.

SOURCES: Monthly series: International Monetary Fund, International Financial Statistics tape.

Trade weights: Morgan Guaranty Trust, World Financial Markets. 
many goods prices which are changed only infrequently, exchange rates are free to respond to any new information hitting the exchange markets.

Even though exchange rates are volatile when compared with price indexes, however, they are less volatile than some asset prices like stock exchange indexes. And exchange rate volatility is also generally lower than the volatility of commodity prices quoted on organized exchanges. Table 2 also reports volatility measures for both sets of variables. Notice that three agricultural commodities important to farming communities, cotton, rice, and wheat, have almost three times the volatility of exchange rates.

That exchange rates are so much more volatile than prices should suggest that the volatility of real exchange rates is also quite large. Table 2 also provides evidence that real rates are about as volatile as nominal rates. This table presents volatility measures of nominal and real bilateral exchange rates as well as nominal and real effective exchange rates. Throughout the paper, the real exchange rate $\left(R_{t}\right)$ is defined as the ratio of the domestic price index $\left(P_{t}\right)$ to the domestic currency value of the foreign price index $\left(X_{t} P_{t}^{*}\right)$ where $X_{t}$ is the domestic currency price of the foreign currency: ${ }^{7}$

$$
R_{t}=P_{t} /\left(X_{t} P_{t}^{*}\right)
$$

The domestic and foreign prices used are wholesale price indexes (or WPI's) which are available on a monthly basis for most industrial countries. Effective exchange rates are obtained by weighting the exchange rates of ten countries ( $G-5$ plus five medium-size industrial countries) by the share of total trade in manufactures (imports plus exports) of one country with each of the other countries. ${ }^{8}$ The lesson to be learned from this table is an important one: real exchange rates are volatile primarily because nominal exchange rates are volatile. That is, the relative stability of price levels 
means that nominal exchange rate volatility translates into real exchange rate volatility .

Excessive Volatility?

Recent studies have addressed the question of whether asset prices are excessively volatile relative to the underlying factors determining their values. Shiller (1979), for example, studies whether long term interest rates are excessively volatile relative to interest rates on short term bonds. He finds that the volatility of long rates exceeds the limits imposed by termstructure models which represent long term rates as averages of expected short term rates. The same type of methodology can be used to investigate the volatility of exchange rates. ${ }^{9}$ But the tests are valid only if the researcher uses the correct underlying model of exchange rates, and there is little consensus about the appropriate model to use. ${ }^{10}$ Huang (1981) shows that exchange rates are excessively volatile relative to a monetary model of exchange rates. But exchange rate volatility has yet to be investigated in terms of other models, so whether exchange rates exhibit excessive volatility remains an open question.

Changes in Volatility over Time

We have lived with flexible exchange rates for over a decade now, but there is no evidence that exchange rate volatility has declined as traders have become more accustomed to flexibility. Figure 2 illustrates the pattern of volatility over time for the real effective exchange rates for the yen and dollar. (The currencies in the European Monetary System, including the Deutche mark, are discussed in Section 3). Volatility is measured over the twenty-four months immediately prior to each time period. The yen and dollar experienced a decrease in volatility in $1976-77$ before being hit by the second 


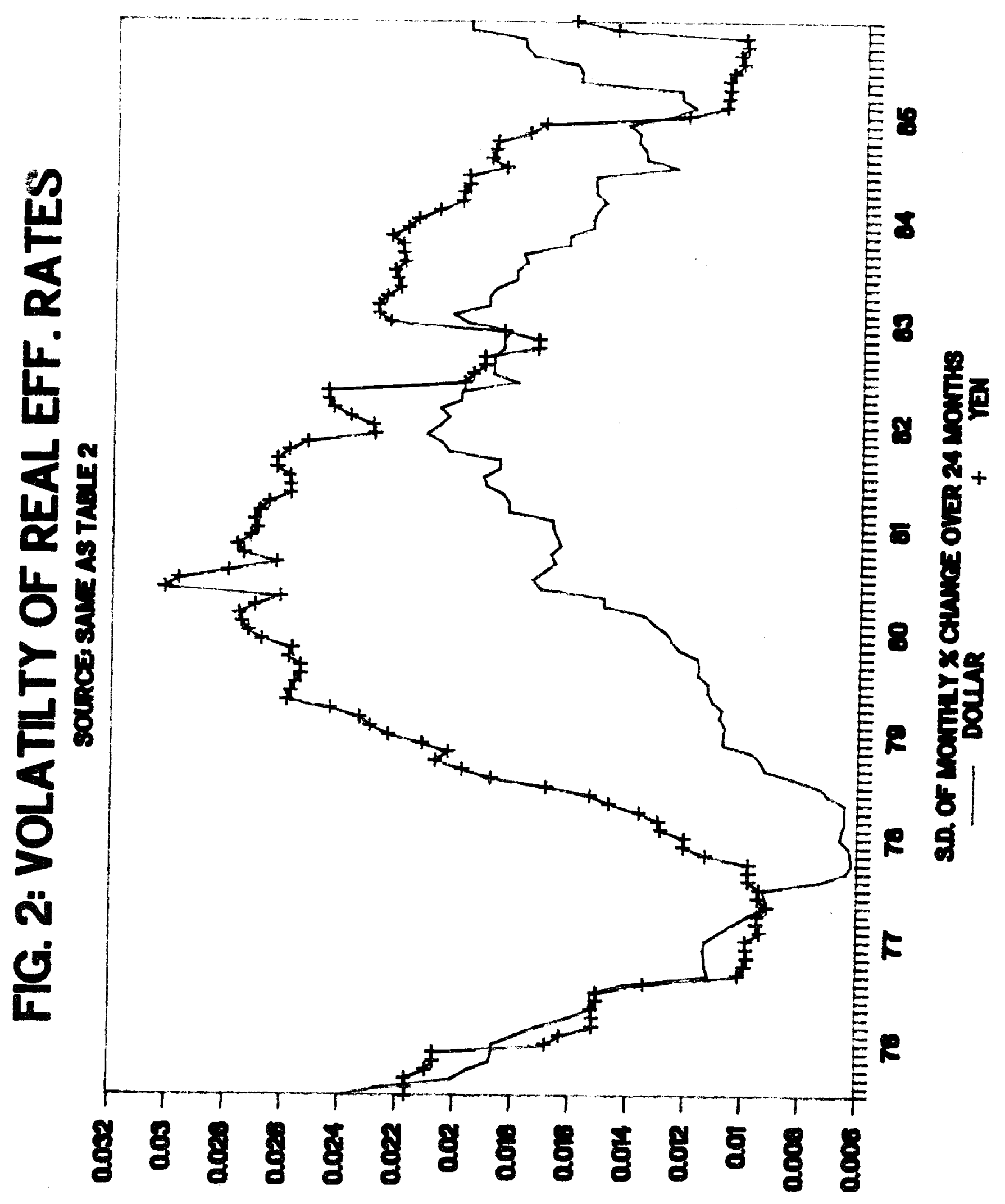


and by changes in U.S. policy (to be discussed below). There are no sous trends in these series.

No doubt exchange rates are much more volatile than they were under the so-called fixed exchange rate regime of the 1960s. Table 3 uses quarterly data for real effective exchange rates to compare volatility during the 1960 s with that of the more recent period from 1973 to 1985. Volatility is defined as the standard deviation of quarterly percentage changes. The results are quite clear: the Bretton Woods System's band around par values did constrain the volatility of real exchange rates. The two currencies experiencing only a marginal increase in volatility, the franc and mark, are those which have been tied together in European exchange rate arrangements, first the SNAKE and more recently the European Monetary System.

\section{Effects on Trade}

To what extent should we concerned with volatility per se? That question is difficult to answer. There is ample evidence that the movements in exchange rates reflected in the volatility measures are mostly

unanticipated. (For example, forward premiums explain only a fraction of the variance of spot exchange rate changes.) So trading firms must cope with uncertainty about exchange rates. In drawing up contracts involving foreign exchange exposure, firms must take into account this uncertainty. They may elect to purchase forward exchange, but the forward market is Iimited to less than a dozen currencies, and for most of these currencies the market is thin for all but the shortest maturities. (Note, however, that limiting hedging alternatives to less than a dozen currencies is less restrictive than it seems since most of the other currencies in the world are tied to the major currencies.). They may use the Eurocurrency markets to hedge their currency exposure, matching assets and liabilities in different currencies (the range 
TABLE 3

\section{STANDARD DEVIATIONS OF QUARTERLY PERCENTAGE CHANGES}

IN REAL EFFECTIVE EXCHANGE RATES

UNITED

STATES

0.0066

0.0281

$$
\text { JAPAN }
$$

FRANCE

GERMANY

FIXED EXCHANGE RATE PERIOD: 1960 I - 1971 I :

0.0070

0.0155

0.0141

0.0162

FLEXIBLE EXCHANGE RATE PERIOD: 1973 II - 1985 IV:

UNITED

KINGDOM

0.0193

0.0391

SOURCES: Same as Table 2. 
of currencies available closely corresponding to the set available in the forward markets). They may take advantage of currency swaps which expand the range of foreign currency instruments available to the average company. Firms may also take advantage of the relatively new markets for options on foreign exchange, particularly when bidding on contracts. Finally, large multinational firms can diversify away much of the exchange risk. These hedging and diversification strategies are not without costs, including the additional managerial effort required to monitor exposure. These costs must be weighed against whatever benefits the present system affords.

Despite strong evidence that exchange rate volatility is much greater under flexible rates than under fixed rates, it has been difficult to establish statistically that this increase in volatility has seriously affected international trade. Hooper and Kohlhagen (1978) studied the effects of volatility on bilateral trade flows of the United States and Germany with other major industrial countries. They found "absolutely no significant effect of exchange risk on the volume of trade" (p. 505). Cushman (1983) found some evidence of reduced trade using the volatility of real rather than nominal exchange rates as his measure of risk. Kenen and Rodrik (1984), using multilateral trade data and effective exchange rates for eleven countries, also found some limited evidence of trade reduction. But for some countries in their sample, higher volatility seemed to increase rather than reduce trade. The strongest evidence in favor of trade reduction effects was provided by Akhtar and Hilton (1984) who examined aggregate export and import behavior in the United States and Germany. Using a longer sample period than Hooper and Kohlhagen who studied the same two countries, Akhtar and Hilton found that German exports and imports were significantly reduced as a result of the increased volatility of nominal effective exchange rates, measured as 
the standard deviation of daily exchange rates. Even that study, however, found that U.S. imports were unaffected by volatility, and U.S. exports only marginally so. How is this evidence to be interpreted? It may be that opportunities for hedging and diversification are sufficient to limit the impact of volatility on trade. But it also may be that our econometric methods are not sufficiently powerful to determine the effects of volatility on trade.

\section{Example of a Trading Firm}

At this point it is useful to remind readers that volatility as defined is very different from the persistent misalignment of exchange rates that we have experienced recently. When the rise in the dollar leads to a loss of competitiveness for U.S. goods of more than thirty percent, as has happened over the last several years, trade is bound to be affected regardless of how successful firms are in reducing the effects of exchange rate volatility.

The distinction between the two concepts can be illustrated by a simple example. Suppose an American firm regularly exports goods to Germany for sale in that country. Whether these goods are invoiced in dollars or marks determines which firm, the American exporting firm or the German importing firm, bears the "transaction risk", the exchange risk associated with a particular export contract. If the mark/dollar (or $D M / \$$ ) rate fluctuates widely around an equilibrium value of $D M 2 / \$$ (i.e., if the DM/ $\$$ rate is highly volatile), that risk can be considerable. The firm bearing the transaction risk, however, may elect to purchase a forward contract to hedge this risk. Alternatively, the risk can be reduced by appropriate financing or diversification strategies. Contrast the same American firm faced with a misalignment of the $D M / \$$ rate at a level of $D M 3 / \$$ (as occurred in the early $1980 \mathrm{~s})$. If this misalignment is persistent, then the firm will find its 
"economic exposure" can not be hedged so easily. The firm may be faced with a choice between shutting down or shifting its production facilities abroad.

\subsection{Misalignment}

Economists writing on flexible exchange rates in the 1960 s contemplated neither the magnitude nor the persistence of the changes in real exchange rates that have occurred in the last fifteen years, so the term "misalignment" is a relatively new one. In his recent study of exchange rates, Williamson defines misalignment as the "persistent departure of the exchange rate from its long run equilibrium level" (Williamson, 1985, p. 13). Defining such a long run equilibrium is no simple task. Williamson identifies the long run equilibrium exchange rate as

that which is expected to generate a current account surplus or deficit equal to the underlying capital flow over the cycle, given that the country is pursuing 'internal balance' as best it can and not reștricting trade for balance of payments reasons $[p .14]$.

It is evident that such a definition refers to the real rather than the nominal exchange rate, so the nominal exchange rate has to be adjusted by relative prices through time if inflation differentials are significant. This is analogous to calculating a purchasing power parity (or PPP) exchange rate relative to some base period. But Williamson's concept of the long run equilibrium rate is more sophisticated than a PPP concept since it also takes into account real shocks such as the OPEC price increases of 1973-74 and 197879.

This paper will discuss some of the problems involved in defining longrun equilibrium when we analyze target zones for exchange rates. In this section, there is no need to be specific about what is the equilibrium level of any exchange rate in order to illustrate the extent of movement of real exchange rates over time for some of the major currencies. In Figure 3 one 


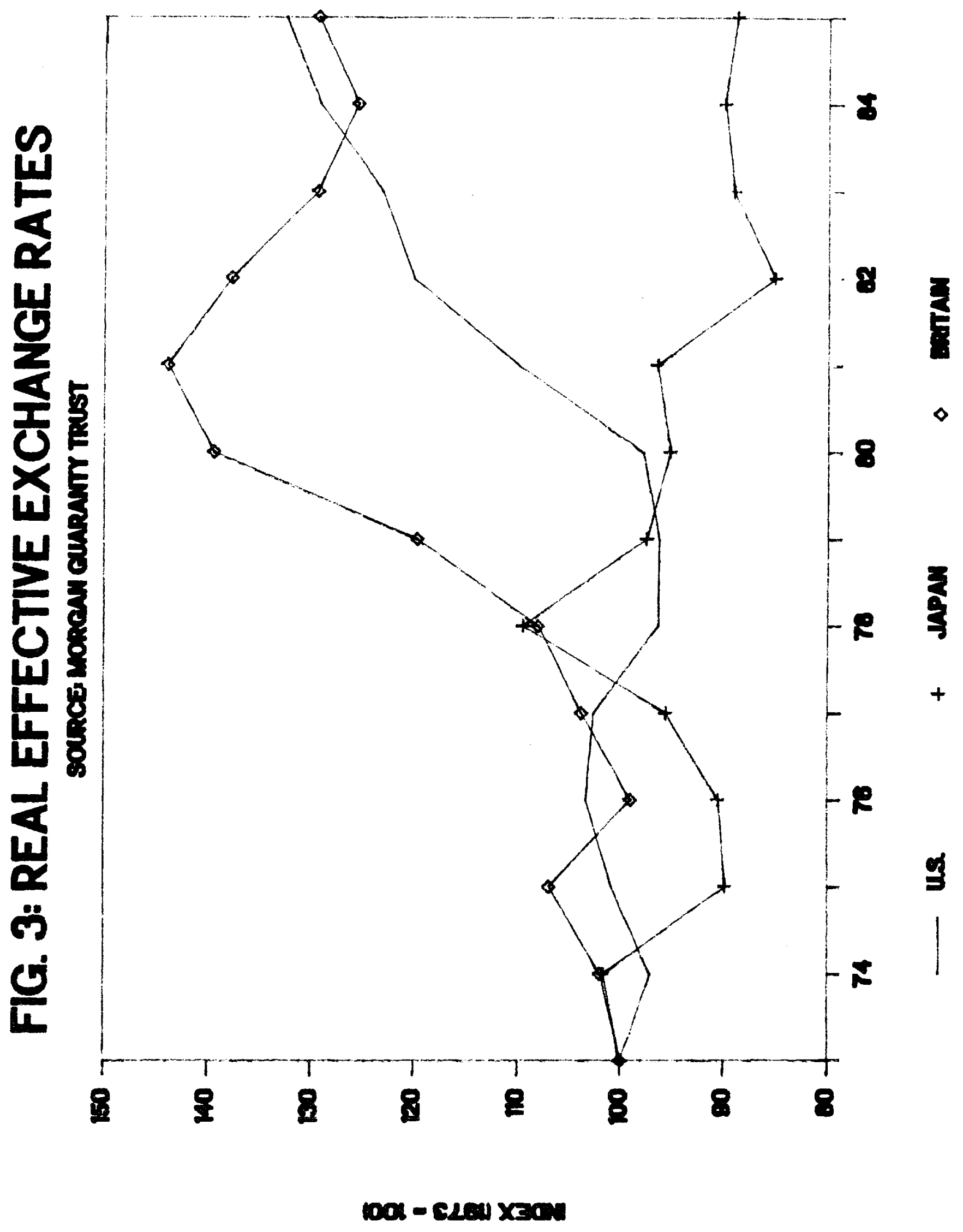


commonly cited measure of real exchange rates, real effective exchange rates based on wholesale prices in manufacturing, is used to illustrate the movements of the dollar, yen, and pound sterling over the period since the start of floating in 1973. The series illustrated are provided by Morgan Guaranty Trust in its World Financial Markets. The figure illustrates clearly the wide swings in real exchange rates which have characterized these currencies. 12 In the period since 1973, the most serious cases of misalignment among the industrial countries occurred with respect to the pound sterling and the dollar. Between 1976 and 1980, the pound rose by over forty percent in real effective terms. Between 1980 and 1985 , the dollar rose more than thirty-five percent using yearly averages. ${ }^{13}$ Its peak in February 1985 was forty-two percent above its 1980 average. Both cases of misalignment will be studied in detail in order to show the extent of the misalignment and its effects on the economies concerned. Before doing so, however, the paper will discuss some of the costs associated with misalignment to show why there is so much concern about it.

\section{Costs of misalignment}

When real exchange rates are misaligned, there are incentives to shift resources both internally and externally. Internally, whenever the rate is overvalued, services and other so-called "nontradable" industries gain at the expense of export and import-competing or "tradable" industries. Externally, foreign competitors gain at the expense of these same industries. These shifts in resources are costly. ${ }^{14}$

Misalignments of the size experienced recently, where competing countries gain a price advantage of 20 or 30 percent, can have very disruptive effects on firms producing traded goods. Since misalignments may persist for five years or more, production facilities in some tradables industries may be 
mothballed or scrapped altogether even though these facilities might be internationally competitive at exchange rates closer to their long run equilibrium levels. Short-run losses of competitiveness due to misalignment can easily become permanent in cases where foreign firms are able to establish themselves in an industry. Baldwin and Krugman (1986) have shown that such irreversible changes can occur in industries where costs of entry (e.g., investment in marketing and distribution) would deter foreign competition in the absence of the misalignment.

If a firm is a multinational, it might elect to shift the production facility threatened by the misalignment to lower-cost countries. That decision is not without peril, however, since today's undervalued exchange rate might swing to overvaluation as did sterling in the late 1970s. A firm electing to locate a production facility in Britain in the mid 1970s would have been unpleasantly surprised by the real appreciation that followed.

Even if domestic production facilities are merely mothballed, moreover, the resulting unemployment is costly. Given sufficient time, the labor force can be retrained and reassigned to non-tradable industries. But even if such shifts of employment between industries can be effected, the costs involved are still significant. The decision to shift to a new industry is made more difficult by three factors. First, it is as unclear to the labor force as it is to firms how long the misalignment will last. The decision of employees to seek employment elsewhere or of firms to close facilities must be made despite the considerable uncertainty about the timing of any return to equilibrium. (Recall the uncertainty about the timing of the dollar's fall). Second, it is hard to disentangle long run shifts in comparative advantage from misalignment. The U.S. steel and automobile industries, for example, were no doubt hurt by the misalignment, but the growth of foreign production was 
important as well. Third, there is the uncertainty about future protectionist measures which might shield an industry from both misalignment and secular declines in competitiveness. These sources of uncertainty make it difficult for both the labor force and firms to make decisions. In the early 1980s auto workers, for example, had to decide whether to retrain and possibly relocate on the basis of their assessment of the duration of misalignment, the long term prospects of the auto industry, and the political economy of protectionism. This was a formidable task indeed--one certainly beyond the skills of economists.

The costs of misalignment are not limited to the firms and labor force in the tradables sector. First, the economy as a whole must adjust its consumption of nontradables if the resources shifted to that sector are to be fully employed. Since the relative price of tradables has fallen, that shift in nontradables requires an increase in total consumption relative to its long run sustainable level. A capital account surplus will finance this consumer surge, but at the cost of a buildup of debt. So one of the costs of the misalignment, as emphasized earlier by Hause (1966) and Johnson (1966), is a major shift in the time pattern of consumption. ${ }^{15}$ The second cost is one alluded to earlier, the cost of tariffs and other protectionist measures which may be introduced in response to the misalignment. In his study of trade tensions between the United States and Japan, Bergsten (1982) points out the three recent periods when protectionist pressures were at their height in the United States were times when the dollar was most overvalued relative to the yen. The costs of protectionist legislation if enacted, which would be "justified" by the need to protect the tradables industries, are borne by consumers throughout the economy. 
Some of the costs associated with misalignments are illustrated by the two most serious cases of misalignment among the major industrial countries, those of Britain and the United States.

The misalignment of sterling in 1979-82

The run-up of sterling began before the Conservative Government led by Margaret Thatcher took office in June 1979, but during the first three years of that Government the misalignment problem became severe. Sterling rose from $\$ 1.70 / \mathrm{E}$ in 1976 to $\$ 2.40 / \mathrm{E}$ in 1980 . The rise in the nominal value of sterling, moreover, was matched by its rise in real terms. Figure 3 above shows a rise in the real effective exchange rate for sterling by $45 \%$ between 1976 and 1981. Recall that this series for the real exchange rate is based on manufacturing prices, so the rise in the index reflects a starting loss of price competitiveness in Britain's principal export sector. A real appreciation of this magnitude led to what was called at the time the "deindustrialization of Britain."

This appreciation is usually attributed to two main factors: the discovery and exploitation of North Sea oil and the commitment to tight monetary policy by the Thatcher government. Although North Sea discoveries began in the early 1970s, production rose sharply only in the late 1970s, from 16.6 million tons in (the financial year) $1976-77$ to 79.6 million tons in 1979-80. 16 So the timing of sterling's rise coincides roughly with the rise in North Sea production (although not with the exchange market's anticipation of this $\mathrm{rise}$ ). In a detailed study of economic policies under the first Thatcher Government, however, Buiter and Miller (1983) find that at most 10 percent of the real appreciation can be attributed to the effects of North Sea oil. 17 The second factor, tight monetary policy, also undoubtedly played a role in the appreciation. The appreciation, however, may have been due more 
to the announced targets for money growth rather than actual money growth performance, since actual money growth (at least for the broader aggregates) repeatedly outran the targets. After evaluating these and other explanations of the appreciation, Buiter and Miller conclude that much of the appreciation remains unexplained; indeed, they "find the decline in competitiveness puzzling" (1983, p. 317$)$.

How much of this real appreciation represents misalignment of the real exchange rate from its equilibrium level? The discovery of North Sea oil shifted the equilibrium real exchange rate, so some of the loss of competitiveness of British manufacturing might be better termed "realignment" rather than "misalignment." That is, some of the real appreciation of sterling reflected the necessary adjustment of relative prices called for by this real shock. But what about the real appreciation due to the monetary tightening (or prospective monetary tightening)? If misalignment is defined as the departure of the exchange rate from its equilibrium level, then the overshooting of the exchange rate associated with monetary tightening should be labelled misalignment. The monetary policy itself may have been desirable as part of a disinflation policy, but the accompanying temporary overshooting of the exchange rate imposes adjustment costs which are just as severe as when the exchange rate becomes misaligned as a result of exchange market inefficiences or speculative bubbles.

The effects of the appreciation on the British manufacturing sector were usually severe. Value added in manufacturing fell by over $8 \%$ in 1980 and by over 6\% in 1981 compared with declines of $2 \%$ or less in GDP in these same two years. The effects on employment in manufacturing were slower to develop, but appear to be longer lasting. According to Figure 4, employment in manufacturing declined by over $4 \%$ in 1980 , but by over $10 \%$ in 1981 , and it 


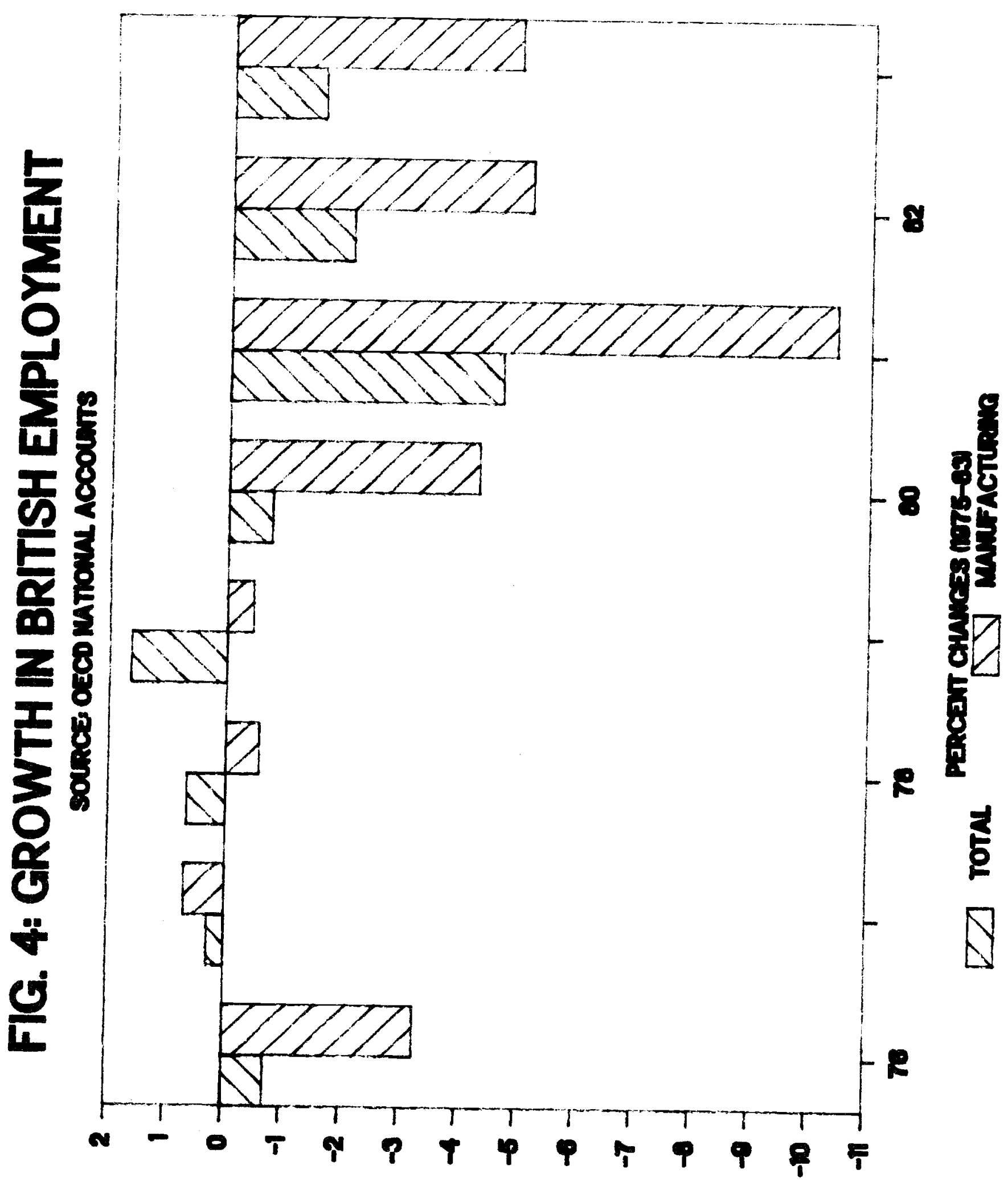


continued to decline in 1982 and 1983. The effects of sterling's loss of competitiveness were devastating for British manufacturing. The term "Dutch Disease" is used to describe the loss of competitiveness of a manufacturing sector when oil or gas discoveries drive up the exchange rate. Britain seems to have suffered from a particularly virulent strain of this disease, although as argued above the causes of the illness cannot be attributed to North Sea oil alone.

Misalignment of the Dollar, 1981-85

The dollar has more recently been misaligned as seriously as the pound sterling was in 1980-82, but the effects of the misalignment on employment have been mitigated by strong domestic demand for U.S. goods. Figure 5 traces three real effective exchange rates for the dollar, all based on prices in the manufacturing sectors of the United States and its trading partners. The three prices represented are wholesale prices, value added deflators, and normalized unit labor costs. The real exchange rates measure U.S. relative to foreign prices or labor costs, so a rise in any of the real exchange rate series represents a real appreciation of the dollar and a loss of competitiveness for U.S. manufactures. ${ }^{18}$ The sharp appreciation of the dollar from 1980 to 1985 is seen in all three series, appreciations of from 34 to 43 percent in five years.

The origins of the appreciation remain a controversial subject. Among the principal causes cited are the fiscal policies of the Reagan Administration, the tight monetary policies pursued by the Federal Reserve Board since Paul Volcker became Chairman in 1979, the rise in investment associated with the Tax Reduction Act of 1981, and the flight of capital to the "safe haven" of U.S. capital markets. Branson (1985) presents the argument in favor of attributing much of the rise to American fiscal 


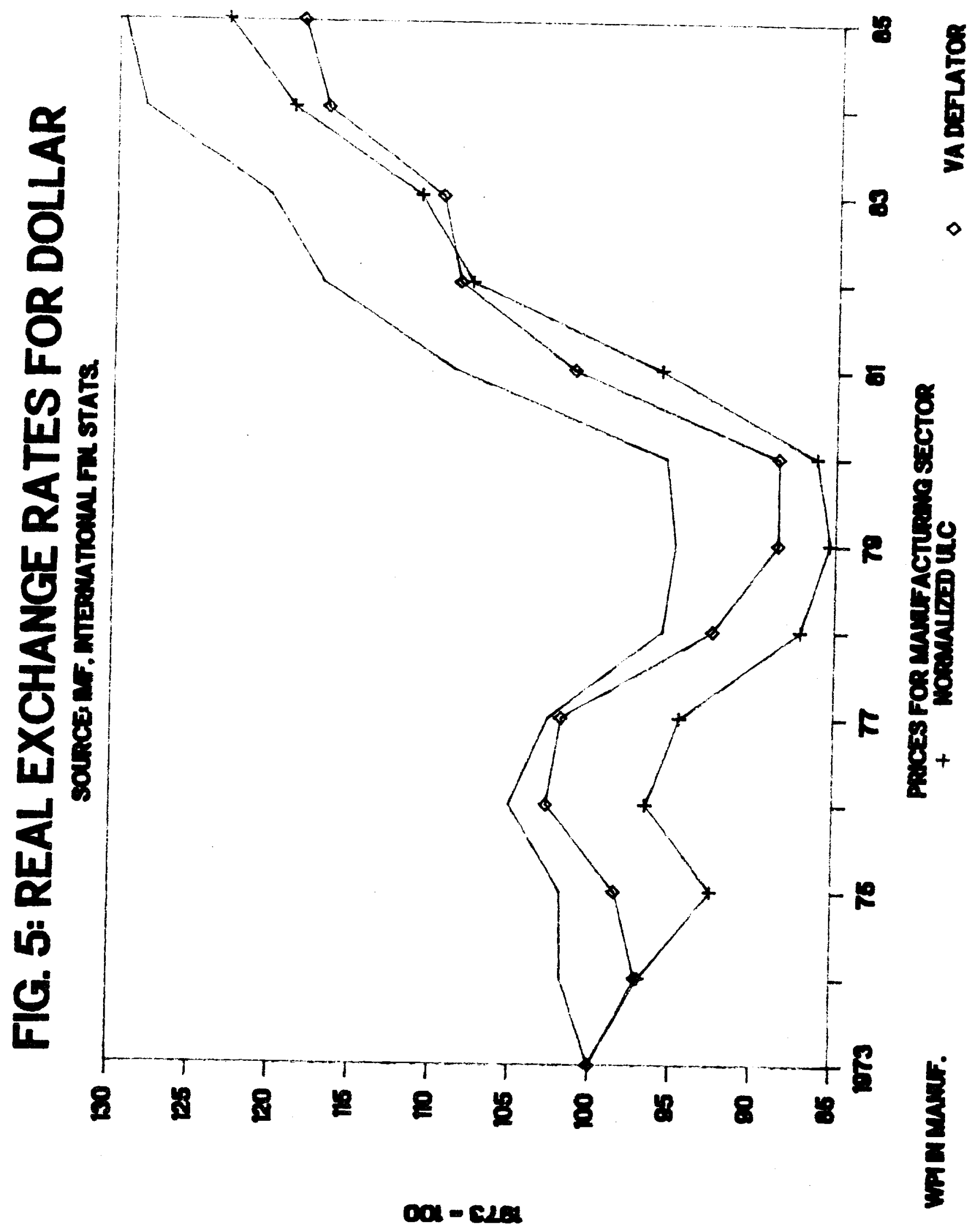


policies. Although the defense buildup and tax cuts were spread out over several years, Branson argues that the Reagan Administration made credible "announcements" concerning this policy in 1981, a year when the dollar rose sharply. Obstfeld (1985) also attributes much of the rise to fiscal policy, but he emphasizes the separate contribution of foreign fiscal authorities. In a back-of-the-envelope calculation of fiscal effects, he attributes to fiscal policy a real appreciation of a little over 20 percent, but almost half of that appreciation is due to foreign fiscal policy. Frenkel (1985) argues that the initial rise in the dollar (in 1980) was due more to actual monetary policy than to expected future fiscal policy. He cites the rise in short-term interest rates which could not have been due to fiscal actions several years in the future. Evidence for the role of investment and the "safe haven" flight of capital is harder to find. Branson points out that while the level of investment rose sharply in the 1983-85 recovery, the level of investment relative to GNP was not unusually high in that period. "Safe haven" effects may have been at work during the period, but it is hard to argue that the degree of political risk in Europe at least was higher in the 1980s than in earlier postwar periods. 19

Unlike the origins of the misalignment, the effects on U.S. trade are unmistakable. The export and importing-competing sectors of the U.S. economy have been hard hit. Table 4 reports the trade balance by sector in two years, 1980 and 1985 , as well as the percentage change in the trade balance over this period measured as a percentage of exports in 1980. According to this table, the sectors hardest hit by the misalignment were the auto and general consumer goods sectors; the trade balance in autos deteriorated by almost $180 \%$ of 1980 exports during this five year period, while the trade balance in general consumer goods deteriorated by over $200 \%$. Even the capital goods sector, 


\section{TABLE 4}

U.S. TRADE ACCOUNT

(IN BILLIONS ON CURRENT \$)

\begin{tabular}{|c|c|c|c|}
\hline & 1980 & 1985 & $\begin{array}{l}\text { \% CHANGE } \\
1980-85\end{array}$ \\
\hline $\begin{array}{l}\text { MERCHANDISE TRADE BALANCE } \\
\text { Agriculture and Raw Materials } \\
\text { Fuels } \\
\text { Manufactures } \\
\text { Capital Goods } \\
\text { Autos } \\
\text { Consumer Goods } \\
\text { Other }\end{array}$ & $\begin{array}{r}-27.7 \\
32.7 \\
-79.1 \\
15.3 \\
43.4 \\
-10.2 \\
-17.9 \\
3.4\end{array}$ & $\begin{array}{r}-122.1 \\
1.3 \\
-50.5 \\
-81.2 \\
11.6 \\
-40.6 \\
-52.2 \\
8.2\end{array}$ & $\begin{array}{r}-43.3 \\
-30.5 \\
36.2 \\
-90.3 \\
-43.3 \\
-179.9 \\
-207.9 \\
57.8\end{array}$ \\
\hline
\end{tabular}

27.18 .1 
normally the strongest of the U.S. manufacturing sectors, deteriorated sharply with the trade balance falling to $\$ 11.6$ billion from a 1980 level of $\$ 43.4$ billion. The trade balance as a whole went from a deficit of $\$ 27.7$ billion in 1980 to an alarmingly large deficit of $\$ 122.1$ billion in 1985.20

The misalignment, of course, was not the sole cause of this deterioration in U.S. trade performance. During the $1980-85$ period, growth in Europe lagged behind that in the United States, causing faster growth of imports in the United States. In addition, the debt crisis forced Latin American countries to curtail their imports from the United States, a factor which may be particularly important in explaining the fall in U.S. exports of capital goods. But the trade sector had to have been seriously affected by a change in relative prices of the magnitude experienced.

The misalignment led to a fall in production and employment in many subsectors of manufacturing. Branson and Love (1986) have estimated disaggregated equations for production and employment in the United States to determine the effects of the dollar's appreciation. They attribute a loss of 1.3 million jobs in U.S. manufacturing to a 40 percent appreciation of the dollar. This job loss was concentrated in the durable goods sectors, with many of these jobs being lost in two of those sectors, primary metals and nonelectrical machinery. Nonetheless, the effects of the dollar's appreciation on industrial production and employment were not as severe as in the case of Britain for two reasons. First, the trade sector is much less important to the U.S. economy than it is to the British. Perhaps more importantly, the appreciation coincided with a defense buildup as well as a consumer boom which kept domestic demand for U.S. goods strong despite the inroads made by foreign goods. 
The two case studies serve to illustrate the disruptive effects of sizable misalignments. One sector of the economy, the tradables sector, suffers inordinately during the period of the misalignment while the rest of the economy stumbles on. During the period of sterling's misalignment, the dichotomy between traded and nontraded sectors took a geographical form. The north of England, where traditional industries such as steel and automobiles were centered, suffered from severe unemployment, while the area around London remained relatively prosperous. In the United States, the contrast in fortunes between the rust-belt and the sun-belt can be explained at least in part by the deterioration of U.S. competitiveness associated with the appreciation of the dollar.

The problems associated with misalignment thus differ markedly from those associated with volatility. No simple hedging strategy can protect a firm from a loss of relative competitiveness of thirty per cent or more.

Having defined these problems of exchange rate variability, the paper now turns to the search for solutions. Some observers might contend that the solution is obvious: governments must adopt policies designed to minimize the variability of exchange rates. Yet the fact that there are costs associated with volatility and misalignment does not in itself justify policies designed to limit exchange rate variability. Before discussing the arguments for and against exchange rate policies, the paper reviews evidence on the effectiveness of the most common instrument used to control exchange rates, foreign exchange intervention.

\section{The Effectiveness of Foreign Exchange Intervention}

The central question addressed in this section is the following: does foreign exchange intervention constitute a separate instrument of exchange rate policy, or does it work solely through its effects on domestic and 
foreign money supplies. If the latter is the case, then intervention must be considered in the broader framework of monetary policy.

\subsection{Definition of Foreign Exchange Intervention}

This section begins with a definition of foreign exchange intervention. Intervention is difficult to define because there are many ways in which the monetary authorities can influence exchange rates. The Working Group on Exchange Market Intervention, commissioned to study foreign exchange intervention by the Versailles Summit of June 1982, adopted a narrow definition of intervention modified to include certain "passive" operations. According to the Working Group's Report (hereafter referred to as the Jurgensen Report), 21 the narrow definition consists of "any sale or purchase of foreign exchange against domestic currency which monetary authorities undertake in the exchange market." It includes all central bank purchases and sales of foreign exchange against domestic currency, whatever form of financing is used (reserves, swaps, official borrowing, etc.). The Jurgensen Report adds to this narrow definition three forms of "passive" intervention: sales concluded by the central bank with public sector entities including the central government (which would otherwise have undertaken the transactions in the exchange market), IMF drawings, and interest payments on international reserves. This definition makes intervention equivalent to the change in the monetary authorities' net foreign currency assets excluding any capital gains on existing assets. The definition specifically does not include exchange market transactions carried out by other private or public entities which might be considered to be "directed" by the government or central bank (such as Eurodollar loans to public authorities) because it is so difficult to establish the intent of the authorities in the case of such transactions. 
More important than the precise definition of intervention is the distinction between sterilized and non-sterilized intervention. The Jurgensen Report defines sterilized intervention as a "change in the monetary authorities' net foreign currency assets which is offset by a corresponding change in their net domestic assets so that their monetary liabilities (or, specifically, the monetary base) remains unchanged" (p. 6). Non-sterilized intervention, in contrast, involves a one-for-one change in the authorities' net foreign currency assets and the monetary base. Non-sterilized intervention thus is a form of monetary policy, distinquishable from conventional open market operations only in the asset being exchanged for money. 22 There is virtually unanimous agreement among economists that nonsterilized intervention can affect exchange rates, just as more conventionally-defined monetary policy can undouttedly affect exchange rates. The effectiveness of sterilized interventior, in contrast, is a much more controversial topic. Yet if foreign exchange intervention is to be regarded as a separate instrument of economic policy, distinct from monetary policy, then it must take the form of sterilized intervention.

\subsection{Effectiveness of Sterilized Intervention}

There are three distinct channels through which sterilized intervention can affect exchange rates. 23 The first is the most straightforward: sterilized intervention works by altering the supplies of assets in private portfolios, thus requiring a realignment of asset returns. This portfolio balance channel requires that foreign and domestic securities be imperfect substitutes. The more substitutable are these securities, the smaller is the realignment of asset returns, and thus the smaller is the change in the current exchange rate, required to rebalance portfolios. In the limiting case of perfect substitution between securities, where investors regard domestic 
and foreign bonds as interchangeable, sterilized intervention is completely ineffective, at least through this portfolio balance channel.

The other two channels operate through announcement effects requiring either market inefficiencies or superior information on the part of the authorities. If the market is inefficient, intervention operations may help to focus the attention of the public on hitherto neglected factors even though the operation itself provides no new information. It is difficult to provide a convincing rationale for why market operators would neglect publicly available information, or why intervention would refocus their attention on this information. But we cannot rule out this possibility a priori. Alternatively, the intervention operation could provide new information by signalling the private market about the future monetary policies of the authorities. 24 This last channel could operate even if the market were efficient, in the sense that market participants incorporate all available information in forming their expectations, since the authorities naturally have superior information about their future intentions.

There is extensive empirical research on the effectiveness of sterilized intervention. Although this evidence is far from conclusive, it is strong enough to have led the Jurgensen Report to conclude that "there was broad agreement among the members of the Working Group that sterilized intervention alone did not appear to have constituted an effective instrument in the face of persistent market pressures" (p. 20). Whether or not sterilized intervention might have a short-term impact through announcement effects was less clear to the Working Group.

The Jurgensen Report's conclusion is based on two different types of evidence. First, there are tests of "speculative efficiency", which are actually joint tests of uncovered interest parity and market efficiency. 
Second, there are estimates of portfolio models designed to determine the influence of bond supplies on risk premia. These two sets of evidence reach sharply different conclusions.

"Speculative Efficiency" Tests

Tests of "speculative efficiency" are based on uncovered interest parity, the equality of expected returns on securities denominated in different currencies. If uncovered interest parity holds, the expected interest return on a dollar security should equal the expected return on a foreign currency security measured in terms of dollars (the expected return consisting of the foreign interest rate plus the expected capital gain or loss on the foreign currency). 25 The expected returns will be equal whenever investors regard the two securities as perfect substitutes. If investors are risk-averse, on the other hand, then they will regard two securities denominated in different currencies as imperfect substitutes, and a risk-premium will separate the two expected returns. In that case, sterilized intervention might be effective if it can change the relative supply of dollar and non-dollar securities enough to affect the risk premium.

To determine whether uncovered interest parity holds, investigators must examine actual, not expected, returns (since expected returns are not observable). Uncovered interest parity does not ensure that actual returns are equal on securities denominated in different currencies. But the differential between these returns should be random as long as the forecast errors from predicting exchange rates are random, which will be the case if the exchange market is "efficient." The "speculative efficiency" test, which tests jointly whether uncovered interest parity holds and the exchange market is efficient, thus examines whether actual returns on securities denominated in different currencies are equal except for a random factor. 
During the 1970s, a score of investigators ran tests of speculative efficiency using different time periods and currencies. With few exceptions, they were unable to reject the speculative efficiency hypothesis. The evidence was strong enough for Mussa (1979, p. 24) to conclude in his summary of empirical regularities in the foreign exchange market that "the interest differential in favor of domestic currency bonds is equal approximately to the expected rate of depreciation of domestic money in terms of foreign money."

Recent studies, however, have been able to reject the speculative efficiency hypothesis using longer data sets and more sophisticated statistical techniques. 26 In fact, they have provided such convincing evidence against speculative efficiency that researchers have turned their attention towards explaining deviations from uncovered interest parity in terms of risk premia (while maintaining the hypothesis that the exchange market is efficient).

\section{Direct Evidence of Risk Premia}

If investors are risk averse, the expected returns on securities denominated in different currencies will be separated by a risk premium which is a function of the relative supplies of foreign and domestic securities, domestic and foreign wealth, and other factors. 27 Investigators have searched for evidence of this risk premia without success. Rogoff (1984), for example, finds no evidence that the interest differential between U.S. and Canadian bonds is sensitive to the relative supply of these bonds. (So he finds no evidence that sterilized intervention in the Canadian dollar market, which would alter the relative supplies of U.S. and Canadian dollar bonds, could affect exchange rates). Other investigators have used more elaborate models to investigate $r i s k$ premia, but have reached conclusions similar to those of Rogoff. 28 


\section{Interpreting the Conflicting Evidence}

The two sets of evidence from speculative efficiency and portfolio balance studies seem to give conflicting results. The studies of speculative efficiency suggest the importance of a time-varying risk premium, but the portfolio balance studies are unable to explain that risk premium in terms of relative asset supplies. There are at least three ways to reconcile this evidence. First, an appeal can be made to market inefficiencies which would account for the ex post interest differentials without appealing to a risk premium. But to date no one has provided a convincing rationale for why traders would fail to eliminate any perceived profit opportunities in the foreign exchange market. Second, it may be the case that, even though a timevarying risk premium is important in explaining interest differentials, sterilized intervention (or any other change in relative bond supplies) has a negligible effect on that risk premium. Third, existing empirical methods may not be sophisticated enough to establish the effectiveness of sterilized intervention. Unfortunately, there is no basis for choosing between these last two alternatives. It is evident that the menu of assets available to investors is much larger than the choice between domestic and foreign bonds modelled in many studies. Portfolio decisions, moreover, have an intertemporal dimension in which consumption and investment decisions are made simultaneously, in contrast to the static models that form the basis of existing empirical estimates. 29 It is unclear whether or not more sophisticated empirical models, based on a larger menu of assets and incorporating intertemporal decisions, would confirm or refute existing empirical evidence. To date, however, there is no evidence that sterilized intervention can affect exchange rates, at least through conventional portfolio balance channels. On the basis of existing evidence, therefore, it 
is difficult to justify using sterilized intervention to carry out exchange rate policy.

If sterilized intervention is ineffective, a second conclusion follows: to pursue active exchange rate management, there is no substitute for monetary policy. Monetary policy can be pursued either with traditional domestic instruments or with non-sterilized foreign exchange intervention. Whether the latter is called monetary policy or not is of little importance.

Yet even if monetary policy is necessary for exchange rate management, there is still a potential role for sterilized intervention if such intervention provides a signal to the market about future monetary policy. Because of the very nature of announcement effects, however, it is difficult to find evidence of them using conventional statistical methods. Two successive intervention operations of equal size may provide different signals to the market, so they may have different effects on the exchange rate.

\subsection{Two Episodes of Foreign Exchange Intervention}

Because statistical evidence leaves the question of announcement effects unresolved, one might believe that the study of specific episodes of active foreign exchange intervention might help to resolve this question. Such episodes are difficult to interpret, but two particularly interesting are singled out for study. These are the November 1, 1978, announcement of a dollar defense package by the Carter Administration and the G-5 intervention of September 1985.

\section{Dollar Defense Package}

This episode bolsters the Jurgensen Report's view that intervention can have significant short term effects. But the ultimate failure of the defense package, despite the fact that the U.S. authorities assembled $\$ 30$ billion for foreign exchange intervention, suggests that short term intervention packages 
alone are not effective unless they are followed by longer term changes in monetary policy. The dollar defense package came at a time when the foreign exchange market was in disarray reflecting the growing loss of confidence in the policies of the Carter administration. In her in-depth study of this crisis, Margaret Greene (1984, p. 28), a senior official in the Federal Reserve Bank of New York, describes the market as follows: "During the last week of October, the selling of dollars reached near-panic proportions, and dollar rates plummeted to record lows against several major currencies." After the President announced an anti-inflation program on October 24 , a program received by skepticism by the financial markets, the authorities sold almost $\$ 1$ billion equivalent of marks. Yet the dollar dropped against the mark from DM1.81/\$ to DM1.72/\$ over the next four trading days. Similarly, the dollar dropped against the yen from $¥ 181 / \$$ to $¥ 178 / \$$.

The package announced on November 1, in contrast to the anti-inflation program, was an impressive one. First, monetary policy was tightened, with the discount rate raised by an "unprecedented" 1 percentage point to a (then) historic high of $9 \frac{1}{2} \%$. (Thus the package had an important monetary policy component.) Second, a $\$ 30$ billion package of foreign currency resources was assembled for future intervention consisting of $\$ 15$ billion in swaps with foreign central banks, $\$ 5$ billion in drawings on the IMF and sales of SDRs, and $\$ 10$ billion in so-called "Carter bonds", U.S. Treasury notes denominated in marks and Swiss francs to be sold abroad.

The market was obviously impressed with the scope of the package and the resolve about future policy which it seemed to represent. By 9:13 a.m. on November 1, the dollar had moved $7 \frac{1}{4} \%$ above the previous day's low against the mark to DM1.83/\$.30 Within 23 minutes, the dollar had moved up another $1 \%$ against the mark while the Desk sold the equivalent of $\$ 69$ million marks, to 
SF $1.567 / \$$ while the Desk sold $\$ 19$ million of Swiss francs, and to $¥ 187.5 / \$$ with the Desk selling $\$ 5$ million. As Figure 6 illustrates, by the time of the closing in London the dollar had risen against the mark to DM1.85/ $\$$ and against the yen to $¥ 186.5 / \$$. By the end of the (New York) day, the dollar had risen to DM1.879/\$ and to $¥ 187.9 / \$$, up seven to ten percent from its lows of the day before. The foreign exchange intervention undertaken by the Desk that day amounted to a little more than $\$ 600$ million, over two-thirds of it consisting of intervention in the market for marks.

The U.S. authorities, in cooperation with the Bundesbank, Swiss National Bank, and Bank of Japan, had to intervene repeatedly in the following weeks as the market tried to test official resolve. Figure 6 shows that the dollar stabilized at around DM1.90/\$ and $¥ 190 / \$$ through the first two weeks of November, then rose somewhat more in the following two weeks. By the end of November, U.S. intervention had totalled more than $\$ 3.5$ billion. On December 1, the spot rates for the dollar were DM1.94/\$ and $¥ 203.5 / \$$, both rates being significantly above the October lows.

This episode illustrates the effectiveness of monetary and exchange market operations in halting a currency's slide. But it also illustrates the limitations of such action if not followed up by more fundamental changes in monetary policy and macroeconomic policy in general. The rise of the dollar stalled in early December as market participants became skeptical again about the Carter Administration's policies towards inflation. Then the dollar was hit by the shock of an OPEC price increase of $14.5 \%$ following the political upheavals in Iran. During the month of December, foreign exchange intervention was almost as sizable as in November, totalling more than 3.1 billion. Yet no new monetary policy initiatives were taken. By the end of the month the dollar had fallen to DM1.828/\$ and $¥ 194.60 / \$$. The short-run 


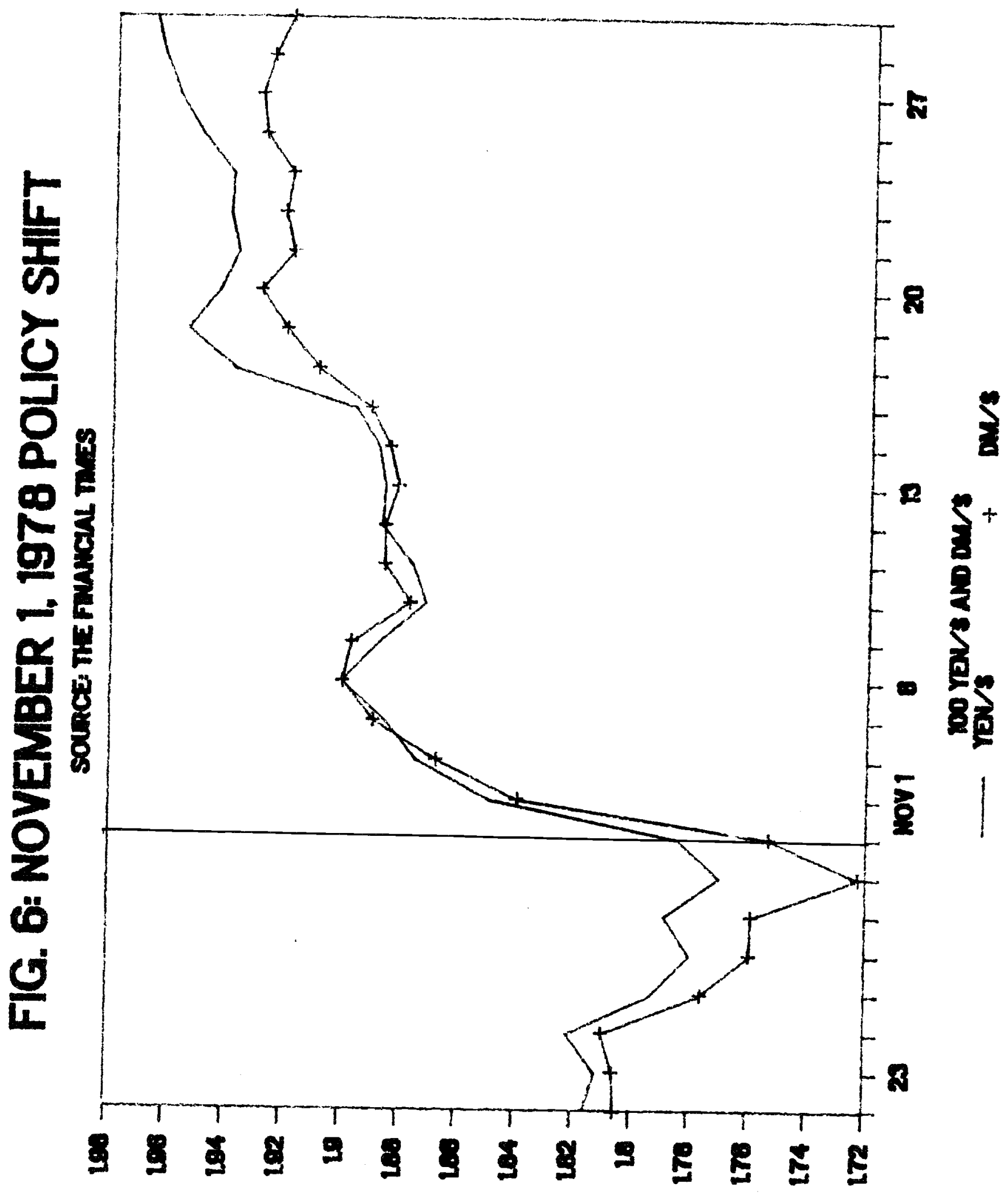


impact of the November 1 package had faded, and the time afforded to make more fundamental adjustments in policy had been squandered. As Greene summarized the episode $(1984$, p. 40): "If this time is not put to productive use, then intervention alone, no matter how large or how well coordinated, will not be effective."

\section{G-5 Intervention in September 1985}

The dollar rose through most of the four years of the first Reagan Administration, peaking in February 1985. After falling from its February highs during the following spring and summer, the dollar began to rally in early September. That rally was cut short by the Group of Five (G-5) meeting of finance ministers and central bank governors in New York on Sunday, September 22. According to the G-5 statement issued at the end of that day (IMF Survey, October 7, 1985, p. 297):

The Ministers and Governors agreed that exchange rates should play a role in adjusting external imbalances. In order to do this, exchange rates should better reflect fundamental economic conditions than has been the case. They believe that agreed policy actions must be implemented and reinforced to improve the fundamentals further, and that in view of the present and prospective changes in fundamentals, some further orderly appreciation of the main non-dollar currencies against the dollar is desirable. They stand ready to cooperate more closely to encourage this when to do so would be helpful. [Emphasis added.]

The statement had an immediate effect on exchange rates. As the Harris Bank Foreign Exchange Weekly Review later remarked: "Foreign exchange traders were taken by surprise, and the dollar dropped sharply following the announcement, even before any official intervention occurred" (February 7, 1986, p. 1). In Figure 7 , daily exchange rates for the yen are illustrated. The dollar fell against the yen from $¥ 240.1 / \$$ to $¥ 231.7 / \$$ by the close in London on Monday the 23 rd. It fell further to $¥ 219.5 / \$$ by Friday of that week. The dollar also 


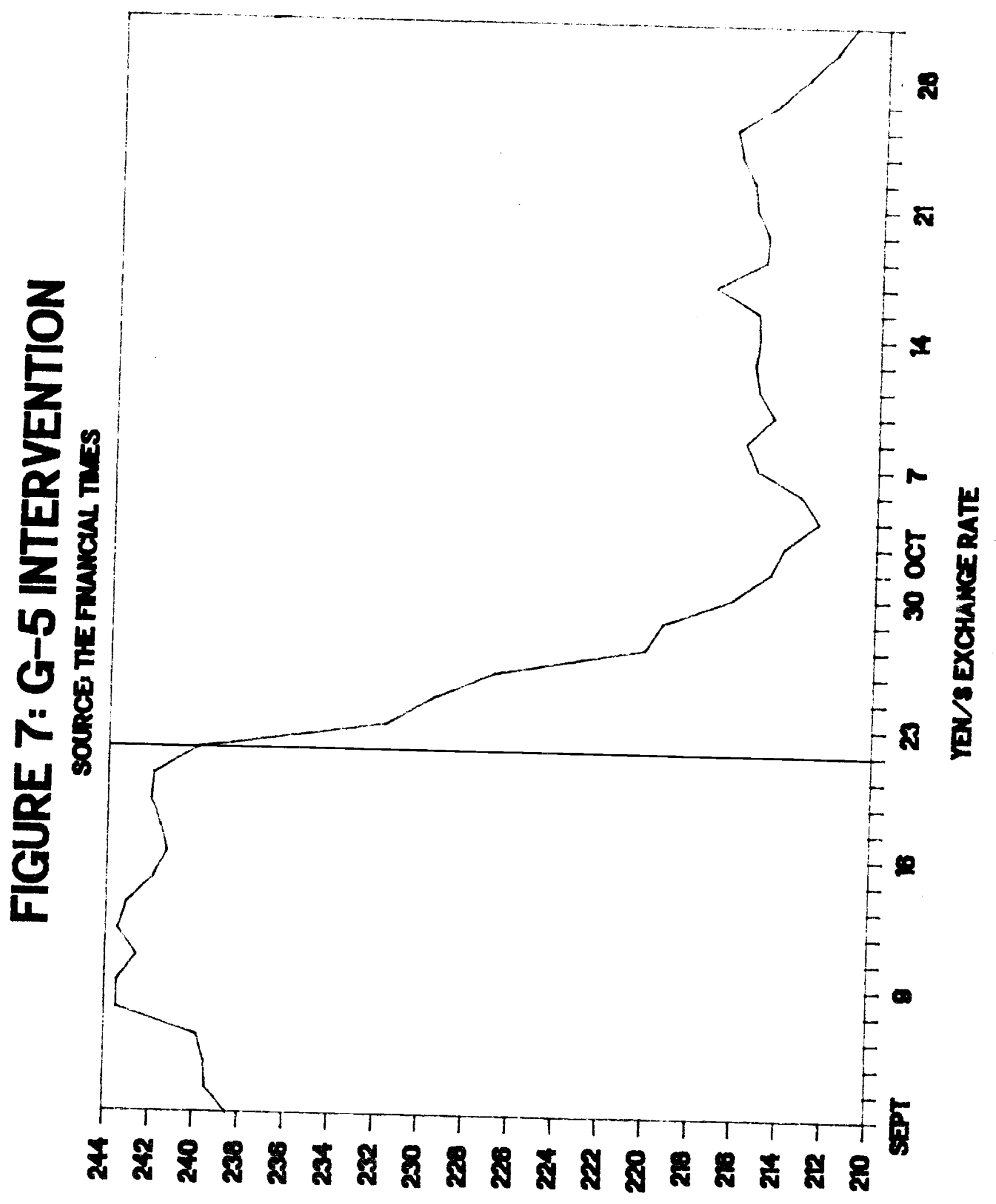

o/Nel 
fell sharply against the mark from DM2.844/\$ on Eriday September 22 to DM2.680/\$ on the following Friday.

There is a puzzle in this dramatic movement. The exchange rates fell despite the fact that interest differentials were virtually constant. In the case of one month Eurocurrency deposits, for example, the interest differential between dollar and yen deposits and between dollar and DM deposits remained roughly constant throughout the week. Indeed, both differentials remained constant until late October when the Japanese authorities tightened credit conditions in their market. The fall in spot rates in the absence of interest rate movements may be due to pure announcement effects of the G-5 communique. That is, the exchange rates may have moved primarily because the G-5 announcement signalled future changes in policy rather than because of the foreign exchange intervention that followed the announcement. This interpretation is bolstered by the fact that, even though foreign exchange intervention following the $G-5$ announcement was not much greater than intervention in February and March of 1985, exchange rates moved much more after the G-5 announcement. 31

What did the G-5 announcement signal? The Bank for International Settlements Annual Report (1986, p. 149) cited two factors. First, the joint communique gave a "convincing demonstration of unanimity and common policy resolve, and . . the subsequent intervention operations were fully coordinated and had the wholehearted support of nearly all the major industrial countries represented." The fact that the policy actions were coordinated was said to be of crucial importance both because of the potentially larger scale of any intervention operations and because there was more of an assurance that the authorities of different countries would not be working at cross purposes. Second, the G-5 statement marked a major change in 
U.S. policy which had shunned foreign exchange intervention since the beginning of the Reagan Administration. As the BIS describes it (1986, p. 149),

[f]rom the point of view of credibility, it was of crucial importance that, for the first time, the US authorities, whose capacity to sell dollars is in principle unlimited, were seen to recognize the need for a further downward adjustment of the dollar.

Yet, given the evidence against sterilized intervention, one must remain skeptical about whether either factor, international coordination or the active participation of the United States, could have been decisive if the G-5 countries had simply announced a series of sterilized intervention operations. Instead, the $G-5$ announcement may have moved exchange rates because the market believed either that the intervention would be monetized or that the intervention, even though sterilized, signalled future changes in monetary policy.

In the case of the G-5 announcement, the evidence is unclear whether or not foreign exchange intervention was monetized. As indicated above, short term interest differentials between the dollar and the mark or yen remained constant from September 22 through most of October. The first unambiguous sign of changes in monetary policy occurred in Japan in the last week of October. The dollar had begun to rally somewhat, so the Japanese authorities decided to tighten monetary conditions, sending short term interest rates from $6.5 \%$ to $8 \%$ in only a few days. As a result, the yen resumed its upward rise. Comparison of These Two Episodes

A comparison of these two episodes is quite instructive. The 1978 defense package bucked a downward trend of the dollar. If it had been the signal for a fundamental change in U.S. monetary policy toward a more restrictive stance, then the short term gains in strengthening the dollar in 
November and December 1978 might have been consolidated and extended into 1979 and beyond. But since no such fundamental change was forthcoming, the dollar resumed its downward trend. The G-5 intervention, in contrast, was clearly reinforcing rather than bucking a trend. In fact, it is useful to ask whether the G-5 announcement and actions that followed were on balance successful in driving the dollar down relative to its previous trend.

Figure 8 tries to answer that question by putting the period immediately following this announcement into longer term perspective. This figure shows the weekly movement of the yen from January through December 1985 , highlighting the G-5 announcement. The trend of the dollar against the yen is downward throughout, but in the period immediately following the announcement the dollar's fall accelerates. The same cannot be said of the dollar's fall relative to the mark. It is true that the G-5 announcement halts a temporary rise in the dollar, but it merely restores that mark to its previous trend. These figures lend support to Martin Feldstein's (1986, p. 6) view that "for Germany and other 65 countries, the Plaza (New York) meeting was essentially a nonevent." Yet even if Feldstein is right about currencies other than the yen, the G-5 period may provide evidence for announcement effects in the case of the yen. Under one interpretation, the dollar fell relative to the yen because the market perceived a greater degree of cooperation between Japan and the United States than in the previous four years, and a willingness on the part of the Japanese government to pursue a tighter monetary policy to drive the yen down, a policy not actually put into effect until late October.

This section has established the limits of foreign exchange intervention as a distinct exchange rate policy. If intervention is monetized, it can have powerful effects on exchange rates, but so also can conventional monetary 


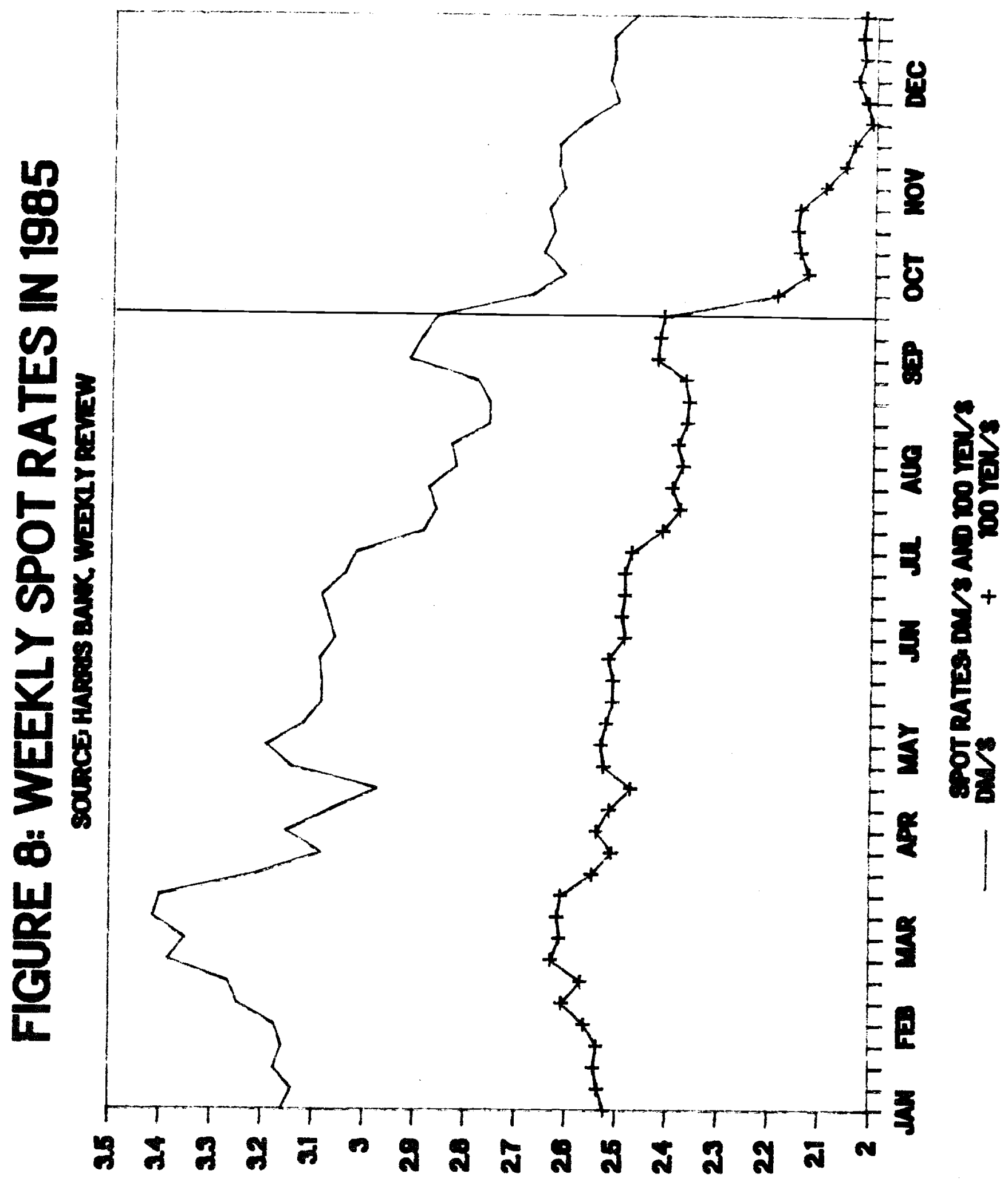


policy. If intervention is sterilized, in contrast, then its effects on the exchange rate are thought to be minimal. The announcement of the intervention may be the occasion for a rally in the exchange market, but perhaps only if the market believes that the intervention signals broader changes in monetary policy.

Because the evidence implies that sterilized intervention is ineffective, the remainder of the paper assumes that monetary policy, broadly defined to encompass non-sterilized intervention, is the prime instrument of exchange rate policy. The discussion now moves from the choice of policy instruments to the design of exchange rate policy.

Exchange rate policy could take a variety of forms. Governments could reestablish a system of fixed exchange rates, perhaps with wider bands to accommodate greater variability of exchange rates. The fixed rates could be confined to regional groupings of countries as in the European Monetary System or encompass all industrial countries. Second, governments could retain the present system of flexible exchange rates, but institute stricter rules governing exchange rate management. Third, governments could establish a system of target zones for exchange rates with "soft margins" which leave governments with some discretion concerning intervention. All three alternatives, which involve systemic changes in the international monetary system, contrast sharply with ad hoc agreements like the G-5 intervention which are designed to cope with specific exchange rate problems. The following sections will explore these alternatives.

\section{Putting Humpty Dumpty Back Together Again: Restoring Fixed Exchange Rates}

This section analyzes the case for returning to fixed exchange rates. The first part considers the general rationale for fixing exchange rates. The next two parts ask what lessons can be learned from two fixed exchange rate 
systems, the Bretton Woods System which lasted until 1971 and the European Monetary System established in 1979.

\subsection{Rationale for fixed exchange rates}

Although many rationales have been offered in support of fixing exchange rates, two are particularly prominent in most discussions. First, fixed exchange rates help to neutralize financial disturbances which might otherwise have an impact on the real side of the economy. Second, fixed rates provide discipline to governments that might otherwise follow inflationary policies. Each argument is considered in turn.

\section{Sources of disturbances}

Economists analyzing exchange rate regimes have of ten posed the following question: Would fixed or flexible exchange rates be preferable in the presence of a particular disturbance? Fixed exchange rates can be shown to be superior when financial disturbances are predominant in an economy. A fall in the demand for money, for example, can be neutralized by a reduction in its supply leaving the exchange rate unaffected. If investors shift from domestic money to foreign securities, this can be neutralized by intervention in the foreign exchange market. In either case, the policy designed to keep the exchange rate fixed also helps to keep the disturbances confined to the financial sector, so that output and employment are left undisturbed. If disturbances originate in the real sector of the economy, however, it is difficult to make a case for preventing exchange rate movements since these movements generally facilitate the adjustment of relative prices which real disturbances require. 32 A rise in demand for exports, for example, leads to an appreciation of the domestic currency under flexible rates since the increase in demand raises domestic interest rates and attracts capital from abroad. The appreciation of the domestic currency, by shifting demand to 
foreign goods, helps to dampen the rise in domestic demand. 33 Thus fixed exchange rates (or target zones for exchange rates to be discussed below) are better designed for periods when financial disturbances are predominant.

Most economists analyzing the desirability of foreign exchange intervention have implicitly assumed that exchange rate fluctuations can be traced directly to a particular disturbance or group of disturbances. The case for foreign exchange intervention is much stronger if exchange rate fluctuations instead reflect excessive volatility due to market inefficiencies. If exchange rates are excessively volatile (as discussed in Section 1), then fixed rates, or at least policies designed to limit exchange rate fluctuations, may be called for even in economies where disturbances are predominantly real in origin. Similarly, if exchange rates are driven by speculative "bubbles," self-fulfilling expectations which depart from market fundamentals, then exchange market intervention may be called for.

In the present context of the misaligned dollar, this characterization of real and financial disturbances takes a more specific form. As mentioned above, many economists trace the appreciation of the dollar during the first four years of the Reagan Administration to the expansionary fiscal policy of that administration. This fiscal expansion represents a "real" disturbance because the defense buildup has shifted expenditure towards U.S. domestic goods (both traded and nontraded). Branson (1986) points out that the appreciation of the dollar has moderated the effects of the fiscal expansion on domestic output and prices by switching domestic and foreign private consumption towards foreign goods. If that appreciation had been prevented through the monetary expansion required to keep exchange rates fixed, then the real appreciation of the dollar required for adjustment in the real sector would have been brought about by a rise in the U.S. price level rather than by 
a nominal appreciation of the dollar. Branson suggests that higher U.S. prices would not have been preferable to the nominal appreciation and consequent fall in the inflation rate that did occur.

If instead of being caused by the fiscal expansion, the dollar's recent rise had been due to a speculative bubble or to a more conventional type of financial disturbance, then the case for fixing the exchange rate would have been stronger. 34 In the presence of financial disturbances, intervention to limit or halt the appreciation of the dollar would have helped to insulate the real sector from the disturbance. Presumably this intervention would have had to have been non-sterilized, in which case the intervention would have involved a significant change in monetary conditions. The question that has to be asked is whether governments are willing to tie their monetary policy to an exchange rate target in such circumstances.

\section{Discipline}

Proponents of fixed exchange rates often base their case on a second rationale: fixed rates impose discipline on national governments since inflationary policies soon run up against a balance of payments constraint. It is true that a government following inflationary policies under flexible exchange rates must contend with the depreciation of its currency, but that same government under fixed exchange rates is likely to have to contend with a highly visible balance of payments crisis. If the crisis results in a devaluation of the domestic currency, that change in currency values is likely to be much more politically damaging than a gradual change in currency values brought about "by the market." This discipline argument for fixed exchange rates might appear to be a persuasive one, especially after more than a decade of high inflation when governments were free to pursue "independent" monetary policies under flexible rates. 
In practice, however, the discipline provided by fixed rates is less than complete for the following reasons:

(1) First, fixed exchange rates exert no discipline over expansionary fiscal policies, at least as long as capital flows are highly sensitive to interest differentials. Higher government spending financed by either taxes or bond issues induces an inflow of capital and a balance of payments surplus rather than deficit. 35

(2) Second, the fixed rate system as a whole has no external constraint unless currencies are tied to an external standard. If $\mathrm{N}-1$ currencies are tied to a reserve currency, as currencies were tied to the dollar under the Bretton Woods System, then there is discipline for the system as a whole only to the extent that the reserve currency country manages to discipline itself. 36 Under Bretton Woods, the United States maintained a relatively stable price level throughout the 1950's and early 1960 's, but during the Vietnam War the Johnson and Nixon Administrations followed what were widely regarded as inflationary policies.

(3) If, instead, all currencies are tied to a commodity like gold, then the increases of the world money supply are dependent on chance discoveries of gold and can be affected by political instability in the producing countries. If the gold supply does not increase rapidly enough to keep pace with real activity, then either the world price level must fall (accompanied, most likely, by a fall in real activity) or banking systems must develop alternative means of payment (as happened in the last half of the nineteenth century). In times of crisis, moreover, governments are unlikely to adhere to the external standard, since the stability of their banking systems is likely to be regarded as more important than the credibility of their external standard. During several banking panics of 
the nineteenth century, even the Bank of England, the stalwart defender of the gold standard system, suspended gold payments in an attempt to stabilize its banking system.

(4) Whether or not the U.S dollar (as the Nth currency) is tied to an external standard, par values for all $\mathrm{N}$ currencies can be changed. Once a par value is changed, future commitments to a fixed rate system are less credible than before, so countries must weigh the benefits of a change in parity against the loss of credibility. A general lesson to be learned from past exchange rate systems is that governments will abandon fixed pegs, even if only temporarily, if exchange rate flexibility will help to ease the adjustment of their economies to a major shock. This was as true of Britain in the nineteenth century, despite its pivotal role under the gold standard, as it was of France and later Britain in the interwar period, and a host of countries in the Bretton Woods period. If governments are likely to abandon pegs in a crisis, then it is necessary to ask what is the value of the discipline afforded by fixed rates. The answer must be that the value of the discipline is highly dependent on how participants in the financial markets assess the commitment of the government to the par value and the likelihood of shocks large enough to alter that commitment. So the discipline argument is less decisive than it appears to be.

\subsection{Weaknesses of the Bretton Woods System}

The paper now turns to an assessment of the Bretton Woods System, the fixed rate system which tied most currencies together during the post-war period until 1971. After fifteen years of flexible exchange rates, many observers look back longingly at this period. As already noted, the macroeconomic performance under Bretton Woods compares favorably with that of 
the more recent period. Against this must be weighed some of the inherent weaknesses of the Bretton Woods System which observers of the time considered major drawbacks of this fixed rate system.

\section{Lack of Monetary Independence}

The Bretton Woods System was often criticized for providing no discipline for the reserve currency country (for the reasons discussed above). The United States, in effect, was too free to pursue an independent monetary policy to the detriment of the system as a whole. But an equally serious weakness of the Bretton Woods System was the lack of monetary independence afforded to other countries of the system. The Bretton Woods System imposed such an extreme form of discipline on these countries that independent monetary policies to deal with disturbances were severely handicapped.

If one country tried to increase its money supply by increasing domestic credit in the banking system, then this led to an incipient decline in interest rates and an outflow of capital which offset, at least partially, the initial increase in the money supply. 37 This offsetting effect of capital flows is characteristic of any fixed exchange rate system with internationally mobile capital.

\section{Capital Controls}

If capital flows offset domestic monetary expansions or contractions, one solution is to restrict such flows with controls of one form or another. That solution was adopted widely under the Bretton Woods System. The recent period of exchange rate flexibility, by no coincidence, has witnessed the progressive dismantling of controls beginning with controls in Germany and the United States in 1974, and Britain in 1978 and Japan in several stages beginning in 1980. Of the major industrial countries during this period, Italy has maintained and France has enhanced their controls, but that is because they 
have had to defend exchange rate parities within the European Monetary System. 38

The overall effectiveness of capital controls in stemming reserve flows is in some doubt since banks and other institutions go to some lengths to find ways to evade controls. But there is no doubt that controls distort investment and borrowing incentives as two episodes from the Bretton Woods period will illustrate.

(1) The Kennedy and Johnson Administrations constructed progressively more complex barricades in an attempt to stem outflows of capital from the United States during the 1960s. In 1963, the Kennedy Administration began with an interest equalization tax on securities issued by foreigners in the U.S. market. The Johnson administration followed with its voluntary credit-restraint program in 1965 which limited the liquid foreign assets that U.S. banks and non-bank financial institutions could hold, and a direct investment program in that same year which compelled U.S. corporations to finance overseas operations with funds raised outside the United States. U.S. banks responded by expanding their operations in London and other foreign centers, in part to serve the U.S. corporations driven abroad for financing. With the arbitrage link between the United States and foreign financial centers severed, large interest differentials developed which reflected the distortionary effects of the controls. At one point in 1969, the three-month Eurodollar deposit rate rose to $11.5 \%$ at a time when U.S. Treasury bill rates were at $7.7 \%$ and U.S. certificate of deposit rates (because of the Federal Reserve's Regulation Q) remained fixed at $6 \%$. Such remarkably large differentials distorted financing decisions by U.S. and foreign corporations. The controls also had the unintended effect of giving 
infant industry protection to the Eurodollar and Eurobond markets in London .

(2) Similar interest differentials developed between Germany and the Eurocurrency markets in response to a network of controls which the German authorities built beginning in 1971. The controls were progressively tightened in an attempt to close loopholes, finally extending to nearly all claims by non-residents to residents, until they were removed in early 1974. Figure 9 compares the internal German interest rate (on interbank loans) with the Euromark deposit rate (which is always approximately equal to the covered Eurodollar rate). The figure illustrates very clearly the effects of the controls which were designed to limit inflows rather than outflows of funds, and therefore led to a higher interest rate in Germany than in the market for mark deposits in London. At one point in early 1973, the differential between the internal and external markets reached the remarkably high level of 11\%. That is, an interbank loan in Germany carried an interest rate $11 \%$ higher than a mark-denominated loan, perhaps made by the same bank, in the Eurocurrency markets. With differentials that large, there is no doubt that considerable managerial effort was expended in finding ways to evade such controls.

The U.S. and German controls were not isolated examples. In fact, controls were the norm during the Bretton Woods period. As discussed below, they are also a prevalent feature of the European Monetary System.

\section{Exchange Rate Crises}

In the 1960's there was a tendency to blame private agents in the financial markets for the "speculation" which brought on balance of payments crises. Thus, for example, British Labor Government ministers characterized 


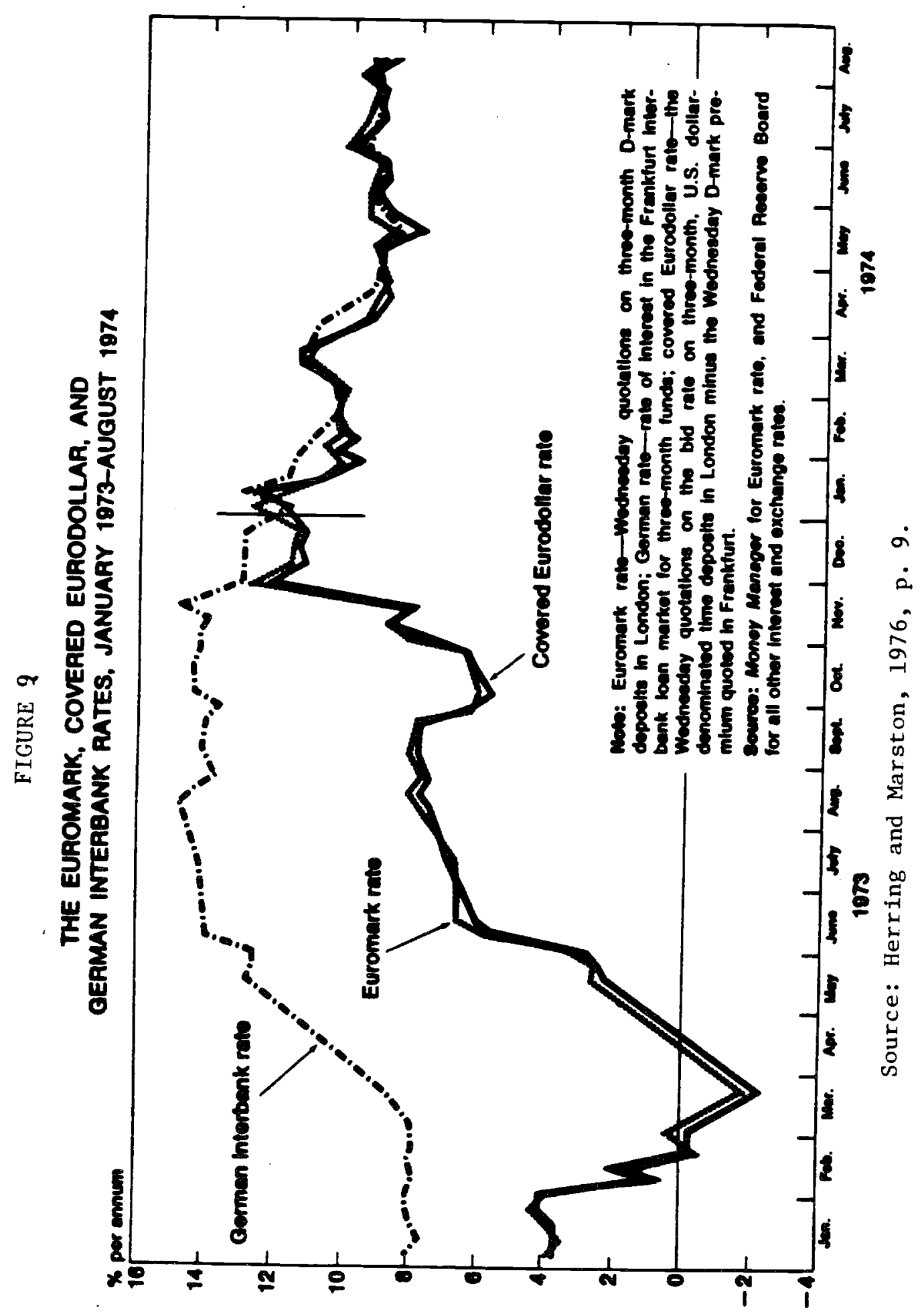


speculators who took positions against the pound as the "Gnomes of Zurich". More recently, however, international economists have formulated "balance of payments crisis" models whose central actors are these same Gnomes, now transformed into rational investors who speculate against governments. These governments, in turn, blindly follow domestic credit expansions that are unsustainable. The Gnomes help to accelerate the date of the crisis, a crisis that is in any event inevitable, but otherwise act like responsible citizens.

There is no doubt some truth in both views of balance of payments crises. As politicians of the 1960 s knew only too well, increased capital mobility makes it more difficult for governments to sustain parities that are under attack by speculators. But, on the other hand, the decision to change parities is often dominated by political considerations because governments have committed themselves to defending parities. When parity adjustments justified by economic factors are postponed on political grounds, speculators attempt to force the government's hand. The government may respond by instituting restrictive macroeconomic policies simply to defend a parity value, policies which under a flexible rate system it might be able to avoid. Or it may attempt to shield its reserves from attack by restricting capital movements. Whether the government successfully defends the parity or not, the country loses. If the parity holds, the economy is disrupted by the crisis and by the policies which have been adopted to defend the parity. If the parity collapses, speculators win capital gains at the expense of the central bank. We illustrate several of these features of exchange rate crises by describing the sterling crisis of the mid-1960's.

\section{The Sterling Crisis}

This crisis began building at the time when Harold Wilson's Labor Government came to power in October 1964.39 The Wilson Government chose not 
to devalue at that time despite a strong economic case that devaluation would help restore British competitiveness. One prominent reason given for the decision was the Government's fear that it would be identified as the "devaluation party," the Labor Party having devalued (in 1949) the last time it was in power. (This is a good example of the discipline provided by a fixed rate system, although in this case the discipline postponed needed adjustments).

Having made the decision not to devalue, the Government had to face a series of balance of payments crises beginning soon after attaining office when it had to arrange a $\$ 3$ billion international credit from foreign central banks. (This was at a time when British bank reserves totalled only $\$ 2.6$ billion and the monetary base $\$ 9.1$ billion). The Government managed to surmount each crisis, in part by arranging foreign central bank financing but also by instituting restrictive macroeconomic policies, until the fall of 1967 when the speculative pressure became overwhelming. On the final day before devaluation, Friday November 17, British foreign exchange reserves fell by $\$ 1$ billion (in a country where capital controls were as tight as anywhere in Western Europe) (Solomon, 1977, p. 95). The next day sterling was devalued by 14.3\%. Not only did the Government have to succumb to the pressures of foreign exchange speculation, but in doing so it lost over $£ 350$ million as a result of intervention in the forward markets. 40

In his assessment of the sterling crisis, Robert Solomon, a former senior adviser at the Federal Reserve Board, points out two lessons of the sterling crisis:

It exhibited the potential for, and the impact of, speculative flows in the accounts of a major trading country... . It pointed up the weakness of an exchange rate system in which a change of parity of a major currency became a political issues of the highest order that engaged heads of state; in such a system a change in the exchange 
rate could be excessively delayed, permitting the build-up of a large imbalance which, when action was finally taken to correct it, required massive shifts of resources.

These same two lessons were consistent themes in the exchange rate crises of the Bretton Woods system until its demise in 1971.

These weaknesses of the Bretton Woods System turned opinion sharply against fixed exchange rates, especially after the failure of the Smithsonian Accord of December 1971 (to be discussed below). It was only after a near decade of floating that sentiment turned back against flexible rates, at least in Western Europe where the European Monetary System was established in 1979.

\subsection{The European Monetary System}

The European Monetary System (or EMS) was established on March 13, 1979 to tie together the currencies of member countries in a joint float against the dollar and other foreign currencies. The initial membership of the EMS consisted of all European Community members except the United Kingdom which elected to float freely. 41 All members except Italy agreed to limit fluctuations of their currencies to $2 \frac{1}{4} \%$ around a grid of central rates; Italy adopted a $6 \%$ margin. As stated by the European Council in its Resolution of December 1978, the main objective of the EMS was to create a "zone of stability, in Europe." The following evaluation of the EMS's success in achieving this objective is based primarily on an excellent statistical analysis by Rogoff (1985). 42

\section{Reducing the Variability of Exchange Rates}

This section begins by examining the success of the EMS in reducing the variability of exchange rates. There is evidence that the variability of bilateral exchange rates has been significantly reduced in the EMS. Rogoff measures exchange rate variability by the variances of unanticipated changes in exchange rates. 43 For both nominal and real bilateral rates, the variances 
have fallen for exchange rates between the mark and the other two major currencies, the French franc and lira. In the case of the nominal franc/DM rate, the variance of monthly prediction errors has fallen by two-thirds, while in the case of the nominal lira/DM rate, the reduction has been by almost four-fifths. The results for real exchange rates are less dramatic, but still statistically significant. This is for a period when bilateral rates between the mark and dollar or yen were becoming more, not less, volatile.

Countries in the EMS, however, should be concerned about the variability of effective exchange rates as well as EMS bilateral rates. There is some reason to believe that the stability of intra-EMS bilateral rates is purchased at the price of greater variability in exchange rates between EMS currencies and those of other countries, so the EMS may not have stabilized effective exchange rates. 44 Rogoff shows that among the three major EMS currencies, only the lira has experienced a reduction in volatility for its nominal effective exchange rate. A similar pattern emerges for the real effective exchange rate, with the lira being the only currency among the three to experience a significant reduction in volatility. It should be pointed out that countries outside the EMS, including the United States, United Kingdom, and Japan, experienced statistically significant increases in the volatility of real effective rates, so the EMS may have helped to prevent the volatility of EMS currencies from rising even in the case of the franc and mark. Role of Capital Controls

Another set of evidence, also due to Rogoff, provides an interesting perspective on how the EMS works. Rogoff examined real interest differentials within the EMS. If most disturbances are financial in nature, then foreign exchange intervention that stabilizes exchange rates should also stabilize 
interest rates. Yet, as Rogoff shows, the variability of real interest rate differentials has increased in the EMS, at least between the three largest countries. 45 There are two possible interpretations of this result, neither of them favorable to the EMS. First, disturbances may have been primarily real in nature. But if this is the case, then foreign exchange intervention within the EMS is undesirable (see the discussion of intervention policy above). Or capital controls may have been a major factor contributing to the stability of EMS exchange rates. If the EMS is held together by extensive capital controls, it provides much less of a model for a world exchange rate system.

Giavazzi and Giovannini (1986) present an interesting analysis of the role of French and Italian capital controls within the EMS. Figure 10 reproduces their graphs of interest differentials between the (free) Eurocurrency markets and national markets in French franc and lira instruments. Large differentials between the free and regulated markets emerge at times of exchange rate crises. (In normal times trade credits, which are largely exempt from the controls, are sufficiently large to eliminate any differentials). These interest differentials which emerge in times of crises show how binding the controls are on investment flows. 46 Nonetheless, the controls appear to be essential if the authorities are to defend weak currencies of the EMS from speculative attack. As Giavazzi and Giovannini (1986, p. 473) conclude:

In the present system weak currency countries have to choose between the welfare losses associated with capital controls and the losses arising from the volatility of short-term interest rates, and, as the evidence shows, overwhelmingly opt for the former. Thus capital controls appear to be an important feature of the EMS, which allows weak currency countries to take part in the exchange rate arrangement, without suffering from excessive domestic interest rate fluctuations [p. 473]. 
FIGURE 10
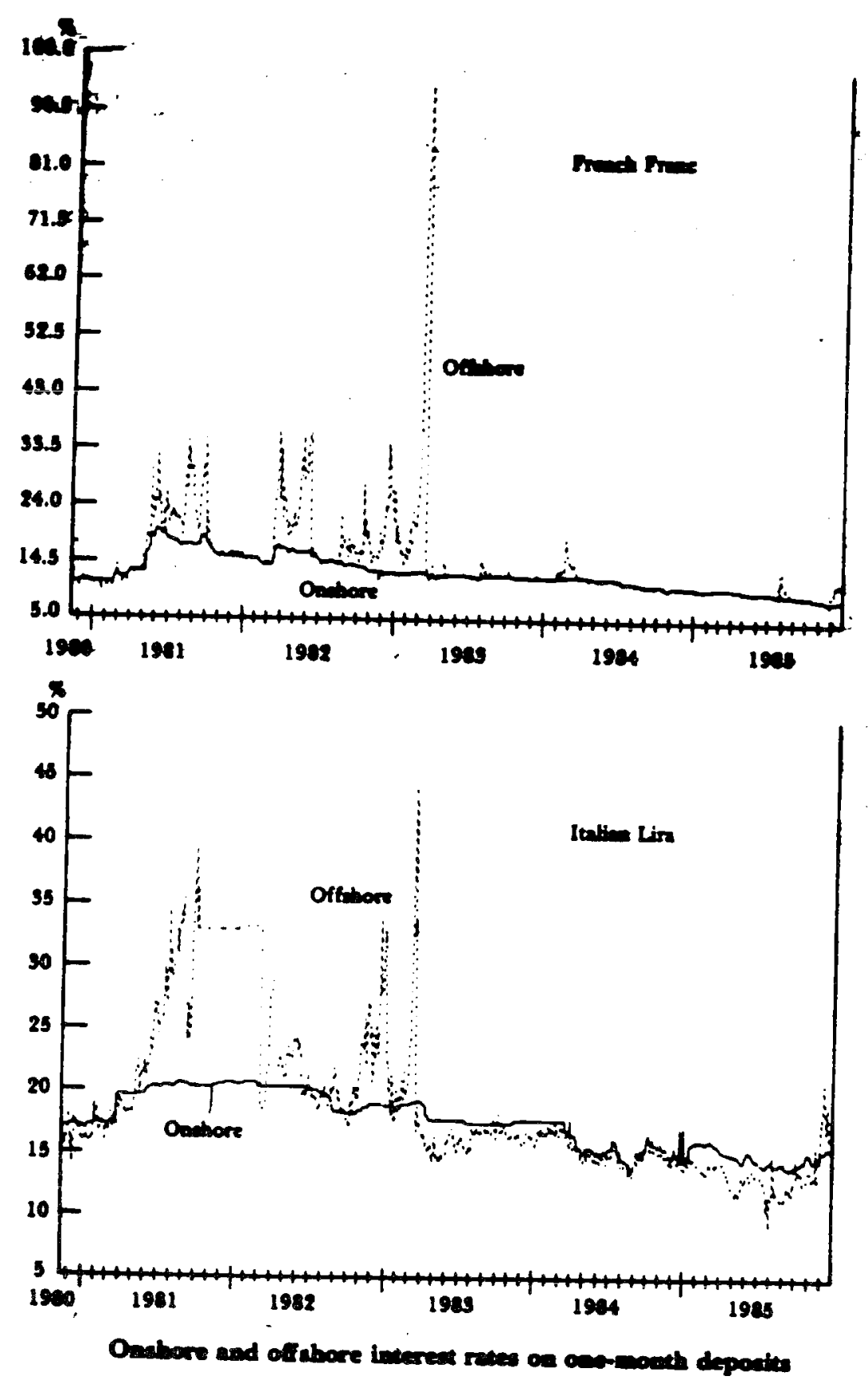

Source: Giovannini and Giovazzi, 1986, p. 468. 
Thus we have in the EMS an exchange rate system which has managed to stabilize bilateral exchange rates within Europe, but only by severely limiting capital flows between the countries of the EMS. Perhaps that is the only way to maintain fixed exchange rates in today's environment.

\section{Other Features of the EMS}

One reason that capital controls are so essential to the EMS is that the system has failed to bring about the convergence of inflation rates among its members, a key objective of the EMS. 47 Rogoff compares five year average inflation rates before and after the establishment of the EMS. He reaches the surprising conclusion that any convergence of inflation rates that did take place was between the inflation rates of Germany and two outside countries, Japan and the United Kingdom.

Because inflation rates have been so divergent, frequent parity changes have been necessary among EMS currencies. There have been eleven realignments since the inception of the EMS. The franc-DM parity alone has been changed six times, the latest realignment being in January 1987, for a cumulative depreciation of the franc relative to the mark of over 27 percent. Similarly, the lira-DM parity has been changed seven times for a cumulative depreciation of the lira of over 38 percent.

Some of the realignments have been quite large. The latest realignment on January 12, 1987, involved a revaluation of the mark and guilder by only three percent and the Belgian franc by two percent. But the April 1986 realignment lowered the franc relative to the mark by 6 percent, while in July 1985 the lira was devalued 7.8 percent against all other EMS currencies and in April 1986 fell 3 percent more relative to the mark and guilder when those currencies revalued by 3 percent. The frequency and magnitude of these 
realignments suggests how difficult it is to maintain a fixed rate system today.

\section{Managed Floating}

The alternative to fixed exchange rates would seem to be flexible exchange rates, but there are many shades of gray in between these two extremes. Present exchange rate arrangements are usually referred to as a system of managed flexibility. There are very few rules to this system, if indeed the term "system" is appropriate to a laissez-faire world. In its 1978 amendments to its Articles of Agreement, the International Monetary Fund did specify certain guidelines for exchange rate intervention. This section begins by examining these guidelines, then turns to several more specific rules for managed floating which have been proposed. Very different from these rules are the taxes on exchange market transactions to be considered next. Einally, "target zones" for exchange rates are analyzed in some detail because they have received so much attention recently.

\subsection{Alternative Approaches to Managing Exchange Rates}

In the 1978 amendment to its Articles of Agreement, the IMF specified three principles that should govern exchange rate policies:

Principle $A$ : A member shall avoid manipulating exchange rates or the international monetary system in order to prevent effective balance of payments adjustment or to gain an unfair competitive advantage over other members.

Principle B: A member should intervene in the exchange market if necessary to counter disruptive conditions which may be characterized inter alia by disruptive short-term movements in the exchange value of its currency.

27.18 .2 
Principle C: Members should take into account in their intervention policies the interests of other members, including those of the countries in whose currencies they intervene. (IMF Survey, May 2, 1977).

It is not easy for a group of governments with different agendas to achieve agreement on a set of policy rules. So it may not be surprising that the principles adopted in this agreement are not specific enough to be binding on any government. Unless there are objective criteria for determining whether or not a country is "manipulating" its exchange rate to gain unfair competitive advantages, for example, Principle A may not prevent such behavior. Even the definition of "disruptive short-term movements" may prove elusive once it is recognized that exchange rates naturally exhibit high volatility. To ensure that these principles are carried out, some have proposed more specific rules of exchange rate management.

\section{Minimal Reform: The "Reference Rate" Proposal}

One of the most interesting proposals was that made by Wilfred Ethier and Arthur Bloomfield (1975) in the Princeton Essay series. These economists, writing soon after the breakdown of Bretton Woods, recognized that a return to fixed exchange rates, whether desirable or not, was simply not feasible. So instead of specifying rules that mandated central bank intervention as had been done in the Bretton Woods System, they proposed rules that prohibited certain types of central bank actions. But unlike the IMF Principles later adopted, they offered objective criteria for evaluating central bank adherence to rules. The "reference rate" proposal which they formulated had two rules (Ethier and Bloomfield, 1975, p. 10):

1. No central bank shall sell its own currency at a price below its reference rate by more than a fixed percentage (possibly zero) or buy its own currency at a price exceeding its reference rate by more than a fixed percentage. This is the sole restriction imposed upon central-bank intervention. 
2. The structure of reference rates shall be revised at periodic prespecified intervals through some defined international procedure.

The aim of the first rule was to prohibit a central bank from driving its currency away from its reference level (thereby "manipulating" its exchange. rate in the language of the IMF's Principle A). For example, a central bank could not drive its currency down to gain competitive advantage for its export industry. At the same time, the proposal did not oblige the central bank to intervene at all. (It is in this sense a "minimal reform" proposal). Nor did the proposal prevent the central bank from "leaning against the wind" to limit movements away from the reference rate.

The authors recognized that their proposal was limited in aim, but it did provide a means to limit the type of competitive depreciations that had plagued countries during the 1930's. In order for this proposal to be successfully implemented, however, countries would have to agree on the reference rates themselves "through some defined international procedure" (their second rule). The discussion of target zones below identifies some of the formidable problems involved in defining equilibrium exchange rates. It also points out how difficult it would be for different national governments to agree on equilibrium rates. Both of those problems carry over to any agreement on reference rates.

\section{Rules for Leaning Against the Wind}

Because volatility itself is viewed as a major problem by some governments, policies of "leaning against the wind" have become common. Such policies are designed to limit the "disruptive short-term movements" addressed by the IMF's Principle $B$. This form of intervention requires minimal knowledge of what factors may be moving the exchange rate, and does not require that the authorities have superior knowledge about the long run equilibrium exchange rate. It does presuppose that exchange rates are too 
volatile in general, and that intervention operations can be effective in reducing this volatility.

There is a danger, however, that central banks might lean against the wind more in one direction than the other, thus imparting a bias to exchange rate movements over time. To ensure against "manipulating" exchange rates in this way, central banks could be required to balance out their net purchases and sales of foreign exchange over a given period. Argy (1982, p. 27) cites one rule that " $[n]$ et reserve changes in a given direction should not persist for more than a few consecutive months (except when reserve levels are excessive or deficient)." Argy, however, goes on to argue that such rules would be difficult to implement, and might even provoke one-way speculation.

If governments wish to limit exchange rate volatility, there is a nonmarket alternative to foreign exchange intervention. This involves imposing a tax on exchange market transactions.

\section{Tobin's Exchange Market Tax}

This tax, proposed by James Tobin (1982), is imposed on each exchange market transaction at a uniform rate, perhaps $1 \%$. The tax has the explicit aim of "throw[ing] some sand in the wheels of our excessively efficient international money market" (Tobin, 1982, p. 489). According to Tobin, a tax of this magnitude is unlikely to make much difference to merchandise trade transactions, since the tax represents such a small proportion of the value of the product and the profit on the transaction. But such a tax is likely to be a much more significant factor in a round trip financial transaction, thus discouraging "hot money flows." It would make overnight or one month roundtrip investments in foreign currencies almost prohibitively expensive. Even in the case of a three month investment, a $1 \%$ tax paid twice in the 
roundtrip transaction could be overcome only by an $8 \%$ differential between interest rates in the two currencies involved.

For a tax of this nature to be successful, it must be uniformly imposed throughout the world, for otherwise financial transactions will gravitate to tax-free zones. The experience of U.S. controls in the 1960's illustrates that point. If such a tax were somehow internationally coordinated, however, it is likely to have a significant impact on the volume of foreign exchange transactions, especially those associated with short term investments. For that reason, the tax may reduce the volatility of exchange rates. But such a tax is unlikely to have a significant effect on the misalignment of exchange rates because longer term investments and trade transactions would remain largely unaffected. William Poole has drawn an analogy between Tobin's tax and a real estate transfer tax. 48 The latter may reduce the volatility of real estate prices, but surely does not affect the longer run level of prices. Nor would it prevent a speculative bubble from developing.

Like the exchange market tax, the reform proposals governing intervention outlined above offer no solution to the misalignment problem. They provide "rules of the game" for managed floating, but they provide little positive guidance for exchange rate policy. The first rule of the reference rate proposal does prohibit central banks from deliberately creating a misalignment through exchange market intervention, but none of the major misalignments experienced recently have been caused by central bank intervention. None of the rules prohibit other macroeconomic policies that can lead to misalignment. Nor do they require that central banks take positive action to prevent misalignments from developing. The paper will consider one type of reform proposal, "target zones," which does address the misalignment 
problem. Since this proposal has received much attention recently, its characteristics will be described in some detail.

\subsection{Targets Zones for Exchange Rates}

In the Bretton Woods System of fixed exchange rates, the national authorities were committed to intervening in the foreign exchange market whenever the exchange rate reached a 1\% "band" on either side of its par value vis-a-vis the dollar. A "target zone" system of exchange rates also has bands for the exchange rate, but these bands are typically much further apart, thus allowing considerable fluctuation in the exchange rate. More importantly, in a target zone system the authorities make no firm commitment to defend those margins. One of the leading advocates of target zones, John Williamson, has described the zone as "a range beyond which the authorities are unhappy to see the rate move, despite not being prepared to precomit themselves to prevent such movements" (Williamson, 1985, p. 64).

\section{Williamson's Proposal for Target Zones}

Given Williamson's central role in the debate over target zones, it is useful to spell out his proposal more fully. ${ }^{49}$ His target zones would involve five elements (Williamson, 1985, 72):

(1) soft margins, rather than a commitment to prevent the rate from straying outside the target zone;

(2) a zone perhaps 20 percent wide (i.e., with 10 percent margins), outside of which rates would be considered 'clearly wrong';

(3) a crawling zone, with the crawl reflecting both differential inflation and any need for balance of payments adjustment;

(4) publication of the target zone; and 
(5) the partial direction of monetary policy, including foreign exchange intervention, to discourage the exchange rate from straying outside its target zone.

The target zone system thus would be a form of managed float with the targets well defined but with national authorities only tentatively committed to intervention or other policy actions.

\section{Anatomy of Target Zones}

Target zones share some of the characteristics of fixed exchange rates, but there are important differences which may be the source of both strengths and weaknesses for this proposed system. The paper next examines some of system's crucial characteristics, then addresses the question of how targets might be chosen.

\section{(1) Wide Bands}

With margins permitting fluctuations of twenty percent, this system is not designed to limit the volatility of exchange rates. Thus hedging by corporations will be as important as in a flexible regime. But if the targets are adhered to and the margins hold, then the system can be regarded as a way of avoiding misalignments.

The wide margins permit those abrupt shifts in speculative sentiment which appear to characterize flexible regimes. Nonetheless, exchange rate crises cannot be ruled out, at least when exchange rates approach the margins. (2) Analogy with National Monetary Targets

Zones are more akin to national monetary targets than exchange rate parities under the Bretton Woods System. Like monetary growth targets, target zones for exchange rates single out one economic variable for special attention without firmly precommitting the national authorities to achieving a specific target for that variable.

27.18 .2 
Yet there are important differences between monetary growth targets and target zones for exchange rates. First, unlike the money growth targets, the target zones provide no continuous guide for policy since the targets are binding only when the exchange rate reaches one of its margins. It is true that in some countries monetary growth targets are set in terms of bands, but these bands are usually much narrower than those proposed for exchange rate targets. Second, the variable targetted, the exchange rate, is an endogenous variable which is normally determined by many factors other than economic policy. It is true that the money supply is also an endogenous variable affected by both bank and nonbank behavior, but the authorities have more direct control over the money supply than the exchange rate.

\section{(3) Anchor for System?}

One of the advantages of a fixed rate system is the anchor such a system provides for inflationary expectations. Target zones provide no such anchor, since the zones are explicitly adjusted for differences in inflation rates. The zones may help to anchor expectations regarding real exchange rates, but only if governments are perceived as being willing to defend the margins.

\section{(4) Commitment to Defend Margins.}

Despite the wide margins around the targets, governments will eventually be faced with the choice between defending the targets or changing them. Economists advising a government faced with a speculative attack are likely to advocate defending the targets only if they view exchange rate movements as part of the problem. (Recall the discussion of economic disturbances in the previous section where exchange rates movements sometimes facilitated, rather than hindered, the adjustment of the economy). Given a permanent shift in the demand for a country's exports, for example, the government would be well 
advised to change the exchange rate target rather than defend it. But if the change is temporary, then defense of the target might be warranted.

(5) The Political Economy of Target Zones

The rationale for target zones is very different if governments are $v$ iewed as the principal source of economic disturbances. Target zones then might have a political rather than economic role to play in stabilization. Proponents of target zones argue that announced exchange rate targets might constrain governments in their macroeconomic policies, much like multilateral tariff agreements constrain national trade policies.

In the specific context of the dollar's misalignment, it is argued that target zones might have encouraged the Reagan Administration to follow a less expansionary fiscal policy. This may be a difficult argument to sustain, however, since in order to pursue its fiscal policy, the Administration overcame much stronger domestic constraints than any international agreement could have imposed.

A better case for the political role of target zones can be made in the European context. A frequent argument in favor of the European Monetary System is that it constrains member countries to pursue policies closely in line with, its largest member, West Germany. The Mitterand Government in France, for example, stayed within the EMS despite being severely constrained at times by the requirements of membership. One major exception to this European pattern is the United Kingdom which has rejected joining the EMS exchange rate arrangements in favor of free floating of the pound sterling.

Perhaps the best that can be said for this political justification for target zones is that it may be relevant to governments predisposed to the constraints or strongly committed to regional or global cooperation. For governments aiming to pursue policies significantly different from those of

27.18 .2 
other industrial countries, target zones may be swiftly discarded if they become a major impediment to such policies.

(6) Objective Criteria for Modifying Targets

The problem of constraining government behavior would be less serious if the target zone proposal did not provide for the modification of targets. Here there is a direct conflict between the politics and economics of international agreements. In order to constrain governments to keep commitments, there should be no exceptions permitted except those clearly specified at the time of an agreement. But the economic arguments for modifying targets in the face of real disturbances may be very compeiling.

To complicate the problem, there is seldom a consensus among experts about the need for changes in real exchange rates. Instead, they may disagree about the nature and scope of a disturbance as well as about its effects on the real exchange rate. Without objective indicators dictating when targets should be changed, the changes will made based at least partly on political considerations.

Consider the recent misalignment of the dollar. Although the appreciation lasted over four years, there is no clearcut consensus about its causes. The appropriate policies to follow if the misalignment is due to the fiscal policies of the Reagan Administration are very different from those to follow if the dollar's appreciation is due to bubbles or to capital flows seeking a "safe haven" or to an investment boom triggered by tax changes. 50 Similarly, although sterling's appreciation lasted over (four) years, economists still dispute whether North Sea oil, tight monetary policies, or other factors caused the appreciation. When there is so much dispute about the causes of a misalignment, there is unlikely to be a consensus about modification of targets. 


\section{Defining Exchange Rate Targets}

If economic conditions are favorable, governments might be willing to precomit themselves to a system of target zones. But formidable problems await the negotiators of such an agreement. Chief among these problems is that of finding (and agreeing upon) appropriate targets. It is useful to follow Williamson's description of how targets might be defined:

(1) The first step in defining a target rate or target zone for the real exchange rate is to decide about the appropriate equilibrium current account balance of each country (or equivalently, the "underlying capital flow" in williamson's terminology since the capital account must be the mirror image of the current account). The equilibrium current account of a developing country like Brazil or Thailand is very different from that of an industrial country like Germany or France. In estimates of his "fundamental equilibrium exchange rate," Williamson makes explicit allowances for such differences among countries. This is not to say that judgments about equilibrium current accounts are easy to make, as the experience of the Smithsonian meeting discussed below makes clear. Not least of the problems is that the negotiating governments will understand the close connection between the current account "equilibrium" agreed upon and the prospects for their leading export industries.

(2) Once figures for equilibrium current accounts are agreed upon, then real exchange rates consistent with them can be calculated using a trade model with its associated trade elasticities. To do so, it is first necessary to adjust the current account for cyclical factors, then to calculate the discrepancy between the equilibrium current account and the cyclically adjusted current account for a particular year. The trade model is then used to calculate the change in real exchange rates necessary to 
equilibrate the current account. 51 Since estimates of price elasticities range widely, this step in the calculation is fraught with

difficulties. Cutting the elasticities in half, for example, requires twice as large a change in real exchange rates to achieve equilibrium.

(3) The calculations so far only determine the equilibrium real exchange rate in a single year. It is then necessary to adjust that rate for real disturbances that occur through time. Among such real disturbances are the oil price shocks experienced twice during the 1970s, natural resource discoveries (such as North Sea oil for Britain), secular movements in demand, and secular movements in supply, including differential productivity growth rates. One issue that arises is whether to take into account changes in government policy if such changes are not just temporary measures but last for a number of years. In his study of exchange rates, Williamson explicitly excludes the shift in U.S. fiscal policy under the Reagan Administration because it is not sustainable in the long run. He also excludes variations in demand or supply over the business cycle from whatever source.

Most of these adjustments require that arbitrary judgments be made. Recall how difficult it was for analysts to evaluate the effects of the first OPEC price increase in 1973. Even the effects of productivity growth are difficult to assess. To illustrate some of the difficulties involved in determining equilibrium rates, the next section examines the Smithsonian Agreement of exchange rates, an agreement reached by the major industrial countries in December 1971. 


\section{Multilateral Agreement on Exchange Rates: the Smithsonian Accord}

The Smithsonian Agreement provides one of the few examples of a multilateral exchange rate agreement, but the lessons to be learned from this agreement are none too encouraging about exchange rate agreements in general.

First, the agreement was reached only after prolonged and sometimes acrimonious negotiations stretching through the fall of 1971 . One of the reasons why the negotiations were so difficult was that the objectives of the participants were inconsistent with one another, which is not surprising given the pivotal role played by exchange rates in each economy. The U.S. Administration wanted to achieve a turnabout of $\$ 13$ billion in its current account through the realignment of currencies. The other major countries of the OECD envisaged, when their individual estimates were summed, a reduction of their current balances of only $\$ 3$ billion (Solomon, p. 199). That an agreement was at all possible in these circumstances is probably attributable to the heavy-handed actions of the Nixon Administration. In August 1971 that administration imposed import surcharge of ten percent in lieu of an agreement to realign the major currencies.

Second, the agreement set new exchange rates that were simply unsustainable in the long run, despite President Nixon's characterization of the accord as the "most significant monetary agreement in the history of the world" (New York Times, December 19, 1971, p. 1). It is interesting to compare the rates agreed upon at the Smithsonian meeting with those prevailing a little over a year later after the Agreement had broken down and most rates were allowed to float. Table 5 presents the central rates agreed upon at the Smithsonian meeting as well as the market exchange rates prevailing in the second quarter of 1973. The market rates diverge from the Smithsonian central rates by more than ten percent in three out of four instances, with the dollar 
TABLE 5

COMPARISON OF SMITHSONIAN AND 1973 2ND QUARTER SPOT RATES

\begin{tabular}{|c|c|c|c|c|c|}
\hline & SMITHSO & PARITIES & 1973 II & $\%$ & \\
\hline & Actual & Adjusted* & Actual & $\begin{array}{l}\text { from } \\
\text { Actual }\end{array}$ & $\begin{array}{l}\text { from } \\
\text { Adjusted }\end{array}$ \\
\hline$\Psi / \$$ & 308.00 & 309.72 & 264.98 & -14.0 & -14.4 \\
\hline$\$ / £$ & 2.6057 & 2.6886 & 2.5300 & -2.9 & -5.9 \\
\hline $\mathrm{DM} / \$$ & 3.2225 & 3.1119 & 2.736 & -15.1 & -12.1 \\
\hline $\mathrm{FE} / \$$ & 5.1157 & 4.8842 & 4.4288 & -13.4 & -9.3 \\
\hline
\end{tabular}

* Smithsonian Parities adjusted for changes in WPI for manufacturing from December 1971 to second quarter 1973.

SOURCES: Bank for International Settlements, Annual Report, 12th June 1972 for Parities; IMF, International Financial Statistics for Exchange Rates; unpublished IMF Data for WPI for Manufacturing.

27.18 .1 
weaker after the advent of floating than before (except in the case of the pound). The table also presents a comparison between the market rates in the second quarter of 1973 and the central rates adjusted for changes in prices in order to see if the divergence was caused by relative inflation rates during the interim period. (Wholesale prices in manufacturing are used to adjust the central rates.) In the case of the yen and pound, the market rates deviate more from the adjusted central rates than from the original central rates; for the other two currencies, the deviations are smaller, but are still about ten percent off the mark. Thus an agreement reached only after prolonged negotiations resulted in an exchange rate realignment that did not go far enough in lowering the value of the dollar.

The obstacles to agreement and to successful implementation of target zones are formidable. As James Tobin, writing in 1978, expressed it: "it is scarcely conceivable that the various OECD countries could individually project, much less agree on, much less convince skeptical markets of, a system of equilibrium or target exchange rates for 1980 or 1985" (Tobin, 1982, p. 493$) .52$

Some advocates of target zones acknowledge the economic arguments against such a system, but nonetheless contend that targets have a role to play in fostering international economic cooperation. They argue that an agreement on target zones at least commits governments to regular consultations on exchange market developments. Even such regular consultations, however, may not induce governments to limit the divergences in macroeconomic policies that cause many misalignments. And if they do not, then this argument for targets loses much of its force. 


\section{Concluding Comments}

This paper began by describing two distinct types of exchange rate variability, volatility and misalignment. Each type of variability imposes its own costs on an economy, and each presents a different challenge to exchange rate policy.

The volatility of exchange rates could be sharply curtailed if the industrial countries agreed to reinstitute a fixed rate system with narrow bands. The EEC has succeeded in fixing bilateral rates within Europe, although fixed rates within the European Monetary System have been maintained only through frequent parity adjustments and through the imposition of extensive capital controls.

In contemplating such a move, however, countries should recall the lessons of the Bretton Woods System. Fixed rates cannot be maintained without extensive capital controls. The paper has analyzed the distortions to investment and borrowing incentives that are entailed by such measures. Balance of payments crises, moreover, will inevitably break out unless frequent parity changes are permitted. But if parity changes are permitted, one of the chief benefits of fixed rates, the credibility given to inflation targets, will be lost. Fixed rates, finally, will inhibit the adjustment to real shocks like the oil price increases experienced in the 1970 s.

Short of fixing exchange rates, countries could pursue more active foreign exchange intervention policies. There might be a role for international agreements to ensure that intervention is confined to leaning against the wind' operations or to prevent intervention from allowing countries to 'manipulate' exchange rates to gain competitive advantages. The analysis of foreign exchange intervention policy above suggests that the 
intervention would have to be non-sterilized, so active intervention would require a compromise of monetary targets.

If misalignment is the most important problem, then the search for an ideal exchange rate policy may be too narrowly focused to be effective. A major source of misalignment in the last ten years has been the macroeconomic policies pursued by countries like the United States and Britain. It is not at all clear that the solution to major policy imbalances among the industrial countries lies in limiting exchange rate movements rather than changing the policies themselves.

The adoption of target zones for exchange rates, on the other hand, may have a useful role to play in inducing governments to modify their policies. At the very least, the breaching of target zones may call attention to the need for international consultations on macroeconomic policies. Whether target zones would be any more successful than the IMF agreements remains to be proven.

The Jurgensen Report concluded that exchange rate policy must consist of more than (sterilized) intervention to be successful. Countries must be willing to commit their macroeconomic policies to controlling exchange rates. In many circumstances, governments may find that limiting exchange rate variability is not worth this price.

27.18 .2 


\section{Footnotes}

* The author is the James R. F. Guy Professor of Finance and Economics at the Wharton School of the University of Pennsylvania and a Research Associate at the National Bureau of Economic Research. He would like to thank William Branson, Martin Feldstein, Dale Henderson, and Richard Herring for helpful comments on an earlier draft.

${ }^{1}$ The passages are from Paris, 1937, p. 166, and Harrod, 1951, pp. 582-84.

${ }^{2}$ Productivity tends to $r$ ise in recovery periods, so the recent $r$ ise in productivity in these two countries may be partly a cyclical phenomenon.

$3_{\text {Later sections discuss how measures of misalignment take into account }}$ real economic shocks (which usually require departures of exchange rates from relative price trends).

${ }^{4} \mathrm{~A}$ useful survey of this literature is Frenkel and Mussa (1984).

5 Kenen and Rodrik (1984) show that other measures of volatility give roughly similar results.

${ }^{6}$ Similar results are obtained for earlier periods by Frenkel and Mussa (1980) and Bergstrand (1983).

${ }^{7}$ If $R_{t}$ measures the real exchange rate of the dollar relative to the pound sterling, for example, then a rise in $R_{t}$ reflects either a rise in U.S. relative to $B r i t i s h$ prices (i.e., $\mathrm{P}_{t} / \mathrm{P}_{t}^{*} \mathrm{rises}$ ) or a fall in the dollar price of the pound ( $X_{t}$ falls reflecting a depreciation of the pound). In either case, a rise in $R_{t}$ reflects a loss of competitiveness for U.S. exports.

${ }^{8}$ Notice how much less variable the effective exchange rates, which represent a diversified basket of currencies, are compared with the bilateral rates (whether nominal or real).

${ }^{9}$ Just because most movements in an exchange rate are unforecastable does not imply that the exchange rate is excessively volatile, although companies engaged in international trade may regard the volatility as too high. Instead, the volatility of an exchange rate is "excessive" if it exceeds that of the factors which determine it.

${ }^{10}$ Meese and Rogoff (1983) examine the out-of-sample performance of several well-known models of the exchange rate, and conclude that a random walk model performs as well as any of these models.

11 Williamson's concept of the "underlying capital flow" is linked to current account targets (as discussed below in the section on "Defining Exchange Rate Targets").

12 It is interesting to note that while the yen was more volatile than the dollar during the period 1973-85, the misalignments of the dollar were larger than those of the yen. This underscores the need to carefully distinquish between the two concepts. 
13 Note that a $r$ ise in the real exchange rate represents a real appreciation of that currency.

14 For further discussion of adjustment costs associated with misalignments, see Branson (1981), Richardson (1984) and Williamson (1985).

15 As pointed out by Williamson (1985), it is interesting that Johnson saw misalignments arising from misguided intervention policy under fixed rates
(maintaining unrealistic parities) rather than from market forces under flexible rates. Like most economists at that time, Johnson did not foresee the large misalignments that were to occur under flexible rates.

${ }^{16}$ See Atkinson, Brooks, and Hall (1985). Note that the second round of OPEC price increases in 1978-79 raised the value of the North Sea discoveries.

${ }^{17}$ If the real appreciation was equal to $45 \%$, then $10 \%$ represents $2 / 9$ of the entire loss of competitiveness. Forsyth and Kay (1980) attribute a larger
proportion of the appreciation to North Sea oil.

${ }^{18}$ These series are obtained from the IMF's International Financial Statistics: Because productivity growth is generally greater in the manufacturing sector than elsewhere in an advanced economy, real exchange rates based on general price indexes (which contain nontraded as well as traded goods) provide a less reliable index of relative competitiveness than real exchange rates based on manufacturing prices alone. For further discussion, see Marston (1986). For a discussion of the relative merits of value added deflators and unit labor costs as measures of international
competitiveness, see Artus (1978).

${ }^{19}$ There is no evidence, for example, that interest rates charged on Eurodollar loans to Europeans rose relative to loans to American residents.

${ }^{20}$ These figures, taken from the national income accounts, are smaller than the balance of payments figures widely quoted in the press, but are more relevant for determining the effects of the misalignment on output and
employment.

$21_{\text {Jurgensen Report, U.S. Treasury, 1983, p. 4. Philippe Jurgensen was }}$ Chairman of the Working Group. The countries represented in this group were the so-called Group of Seven (or G-7) countries: Canada, France, Germany,

${ }^{22}$ Sterilized intervention effectively consists of swapping foreign bonds for domestic bonds, although the operation has several steps to it. Recall that central banks typically hold foreign exchange reserves in the form of interest-bearing, foreign currency-denominated securities. When a central bank wants to intervene in the exchange market, it first sells the foreign securities, then uses the foreign currency so obtained to buy domestic currency from the private sector. If the intervention is to be sterilized, the sale of foreign currency is followed by an expansionary open market operation (or an analogous monetary operation in different institutional acquired domestic currency, thus restoring the monetary base to its initial 
level. For further discussion of such operations, see Girton and Henderson (1977) and Marston (1985).

${ }^{23}$ This description of the three channels draws on Loopesko (1984).

24 Mussa (1981) emphasizes the importance of announcement effects in his study of foreign exchange intervention for the Group of Thirty. See also the recent analysis of announcement effects by Kenen (1986).

25 If $i_{t}, i_{t}^{*}$ are the domestic and foreign interest rates, respectively, and $s_{t}^{e}$ is the expected change in the spot exchange rate (the capital gain on the foreign currency), then uncovered interest parity implies that

$$
i_{t}=i_{t}^{*}+s_{t}^{e} \text {. }
$$

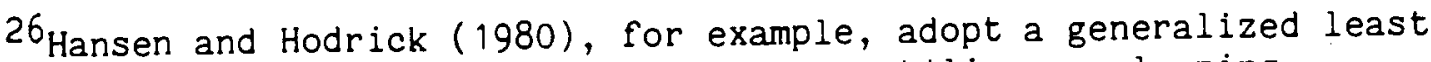
squares estimating procedure so that they can utilize overlapping observations, thus making it possible to use weekly data rather than the monthly or quarterly data typically employed in the past. Cumby and Obstfeld (1984) also use weekly data but adopt techniques to take into account the nonstationarity of the foreign exchange data. These studies and others that have followed are able to reject decisively the joint hypothesis of market efficiency and uncovered interest parity. Levich (1985) provides a comprehensive survey of recent studies.

27 Two recent surveys of the theoretical 1 iterature on risk premia are Adler and Dumas (1983) and Branson and Henderson (1985).

${ }^{28}$ See, for example, Obstfeld (1983), Erankel and Engel (1984), and Danker, Haas, Henderson, Symansky, and Tryon (1985).

${ }^{29}$ Studies of international asset pricing based on intertemporal utility functions include Stulz (1981) and Hansen and Hodrick (1983).

${ }^{30}$ The following account relies heavily on Greene (1984).

${ }^{31}$ For a similar view, see Ueda (1986). Intervention in the autumn of 1985 totalled $\$ 13$ billion compared with $\$ 10$ billion in February and March of 1985 (BIS 1986, p. 149).

32 For a general analysis of foreign exchange intervention in the presence of different types of disturbances, see Henderson (1984).

33 A similar analysis applies to any aggregate demand disturbance. The effects of aggregate supply disturbances on the exchange rate, however, are ambiguous since an increase in aggregate supply lowers prices at the same time that output expands (so nominal output, and hence the demand for transactions balances, may rise or fall).

34 Among those investigating speculative bubbles as the source of the dollar's appreciation are Krugman (1985) and Frankel and Froot (1986). 
35 If a government pursues an expansionary fiscal policy indefinitely, then eventually foreign investors will balk at further exposure to political $r$ isk. But until that point is reached, a country is free to expand through
fiscal means.

${ }^{36}$ If the reserve currency country follows an expansionary monetary policy, the resulting balance of payments deficits are automatically financed, since the country gaining reserves invests them in the securities of the reserve currency country. The monetary base of the reserve currency country, moreover, does not decline as a result of the deficit as long as other countries choose to hold their foreign exchange reserves in the form of securities rather than the monetary base of the reserve currency country. McKinnon (1974) has proposed that all foreign currency reserves be held in the form of central bank balances (bearing a market interest rate). If this were the case, foreign exchange intervention would affect the monetary bases of both reserve and non-reserve currency countries alike.

37 If domestic and foreign securities are perfect substitutes, the attempt by one country to increase its money supply through domestic credit expansion succeeds only to the extent that this one country manages to increase the money supply of the entire system. (The system would be like a set of reservoirs connected by open channels; an attempt to increase the water level in one would succeed only to the extent that the water levels of all were increased). Formal models of the offset phenomenon are presented in Kour $i$ and Porter (1974) and Herring and Marston (1977).

38 In 1986 both Italy and France relaxed some of their controls, but many transactions by residents remain restricted. 1977.

${ }^{39}$ For an excellent account of this period, see Chapter $V$ of Solomon,

${ }^{40}$ Bank of England, Quarterly Bulletin, December 1969, Table 18.

${ }^{41}$ The members were Belgium, Denmark, France, Germany, Ireland, Italy, Luxembourg, and the Netherlands. The United Kingdom formally joined the EMS, but chose not to participate in the exchange rate mechanism. For a detailed discussion of the system, see Ungerer et al. (1983).

42 One of the successes of the EMS which will not be discussed since it lies outside the scope of the paper is the development of the European Currency Unit (or ECU) as a parallel currency. For an interesting discussion, see Padoa-Schioppa (1985).

43 He uses the forward rate as the predicted exchange rate in the case of nominal rates and forecasts of real exchange rates based on a random walk model or a vector autoregression in the case of real exchange rates.

${ }^{44}$ Canzoneri (1982) and Marston (1984) analyze this possibility in theoretical models of exchange rate unions.

${ }^{45}$ The one exception is the real interest rate differential between Germany and Italy formed by using a VAR forecast. 


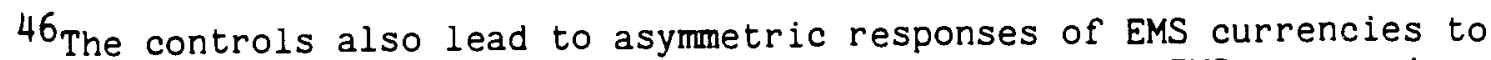
outside disturbances, since among the three most important EMS currencies only the mark has open capital markets. When there is speculative pressure involving the dollar, for example, the mark takes the brunt of this pressure, thus causing strains within the EMS. See Marston (1984).

47 As Jacques van Ypersele, one of the architects of the EMS, has described it: "The objective was indeed that external stability be the result less of artificially imposed constraints than of a convergence of economic trends among member countries, in particular of prices and costs" (Ypersele, 1984, p. 15).

48 See Brainard and Perry, 1986, "Symposium on exchange rates, trade and capital flows," p. 234. Another tax that has been proposed by Leviatan (1980) is the "real interest rate equalization tax." This tax, by creating a wedge between domestic and foreign interest rates, tries to reduce the incentive for outflows (or inflows) of capital when a country abruptly changes its monetary policy. A country trying to stabilize its price level through monetary contraction, for example, would ordinarily have to contend with an appreciation caused by an inflow of capital. By creating a wedge between domestic and foreign returns, however, a country might be able to dampen the currency appreciation. Such a tax is probably best thought of as a supplement to national monetary policies, to be used when one country's policies depart sharply from those of other countries.

49 Earlier advocates of targets for exchange rates include the "Optica Group" of economists from EEC countries. See Commission of the European Communities (1975).

50 Branson (1986) underscores the confusion regarding the source of the dollar's rise by suggesting that misalignment is a "topic . . for the National Science Foundation, not a new Bretton Woods." ( $p$. 176)

$51^{1}$ For further discussion of this approach to estimating equilibrium exchange rates and the problems associated with it, see Artus (1978).

52 There is reason to believe that agreements on equilibrium rates would be even more difficult to achieve in the 1980 s than in 1971. Experts differ widely in their estimates of equilibrium rates today, in large part because of the many structural changes which have occurred since the Smithsonian Agreement. Consider the key bilateral rate between the yen and dollar. Before the dollar recently plunged from $¥ 250 / \$$ to $¥ 160 / \$$, estimates of the equilibrium value of this bilateral rate were as wide ranging as the market rates themselves. Williamson, for example, cites six studies with estimates ranging from $¥ 131 / \$$ to $¥ 209 / \$$. Krause (1986) writes of a possible $¥ 100 / \$$ rate. Changes in energy prices make all such calculations difficult. But another major reason why the yen-dollar rate is difficult to assess is the pattern of productivity growth in the United States and Japan which distorts simple purchasing power parity calculations. (For further discussion, see Marston, 1986.) 


\section{$\underline{\text { References }}$}

Adler, Michael, and Bernard Dumas, 1983, "International portfolio choice and corporation finance: a survey," Journal of Finance, 38: 925-84.

Akhtar, M. A., and R. Spence Hilton, 1984, "Effects of exchange rate uncertainty on German and U.S. trade," Federal Reserve Bank of New York, Quarterly Review, Spring: 7-15.

Argy, Victor, 1982, Exchange Rate Management in Theory and Practice. Princeton Studies in International Finance No. 50. Princeton: International Finance Section.

Atkinson, F. J., S. J. Brooks, and S. G. F. Hall, 1985, "The Economic Effects of North Sea Oil," National Institute Economic Review, November.

Artus, Jacques R., 1978, "Methods of assessing the long-run equilibrium value of an exchange rate," Journal of International Economics, 8 (May): 277 299.

Baldwin, Richard, and Paul R. Krugman, 1986, "Persistent effects of large exchange rate shocks," NBER Working Paper No. 2017, September.

Bergsten, C. Fred., 1982, "What to do about the U.S.-Japan economic problem," Foreign Affairs, 60: (Summer).

Bergstrand, Jeffrey H., 1983, "Is exchange rate volatility 'excessive', New England Economic Review, (September/October): 5-14.

Brainard, William C., and George L. Perry, eds., 1986, "Symposium on exchange rates, trade and capital flows," Brookings Papers on Economic Activity:
$165-235$.

Branson, William H., 1981, "'Leaning against the wind' as exchange rate policy," processed.

Branson, William H., 1985, "Causes of appreciation and volatility of the dollar," in The U.S. Dollar--Recent Developments, Outlook, and Policy Options, Kansas City: Federal Reserve Bank of Kansas City, 33-52.

Branson, William H., 1986, "The limits of monetary coordination as exchange rate policy," in Brookings Papers on Economic Activity, 1: 175-94.

Branson, William H., and Dale W. Henderson, 1985, "The specification and influence of asset markets," in Ronald $W$. Jones and Peter B. Kenen, eds., Handbook of International Economics, vol. 2. Amsterdam: North-Holland,

Branson, W. H., and James P. Love, 1986, "Dollar appreciation and manufacturing employment and output," NBER Working Paper No. 1972, July. 
Buiter, Willem H., and Marcus H. Miller, 1983, "Changing the Rules: Economic Consequences of the Thatcher Regime," Brookings Papers on Economic Activity, 2: 305-65.

Canzoneri, Matthew, 1982, "Exchange intervention policy in a multiple country world," Journal of International Economics, 13, (November).

Commission of the European Communities, "OPTICA report 1975: Towards economic equilibrium and monetary unification in Europe," Brussels, processed.

Cumby, Robert E., and Maurice Obstfeld, 1984, "International interest rate and price level linkages under flexible exchange rates: a review of recent evidence," in John Bilson and Richard C. Marston, eds., Exchange Rate Theory and Practice, Chicago: University of Chicago Press, 121-51.

Cushman, David 0., 1983, "The effects of real exchange rate risk on international trade," Journal of International Economics, 15, (August): 45-63.

Danker, Deborah J., Richard A. Haas, Dale W. Henderson, Steven A. Symansky, and Ralph $W$. Tryon, 1985, "Small empirical models of exchange market intervention: applications to Germany, Japan, and Canada," Staff Studies No. 135, April. Washington: Board of Governors of the Federal Reserve Board.

De Grauwe, Paul, 1985, "The European Monetary System during 1979-84: an evaluation," International Economics Research Paper No. 47, Leuven: Centrum voor Economische Studien, June.

Ethier, Wilfred, and Arthur I. Bloomfield, 1975, Managing the Managed Float, Essays in International Finance No. 112. Princeton: International Finance Section, October.

Feldstein, Martin, 1986, "The impact of economic policies on the outlook for world trade." Remarks delivered to the International Monetary Conference, Boston, Massachusetts, processed.

Forsyth, J. P., and J. A. Kay, 1980, "The Economic Implications of North Sea Oil Revenues," Working Paper No. 10, London: Institute for Fiscal Studies, 1980.

Frankel, Jeffrey A., 1985, "The dazzling dollar," Brookings Papers on Economic Activity, No. 1: 199-217.

Frankel, Jeffrey A., and Charles M. Engel, 1984, "Do Asset-Demand Functions Optimize over the Mean and Variance of Real Returns: A Six Currency Test," Journal of International Economics, 17: 309-323.

Frankel, Jeffrey A., and Kenneth Froot, 1986, "The dollar as a speculative bubble: a tale of fundamentalists and chartists," NBER Working Paper No. 1854, March. 


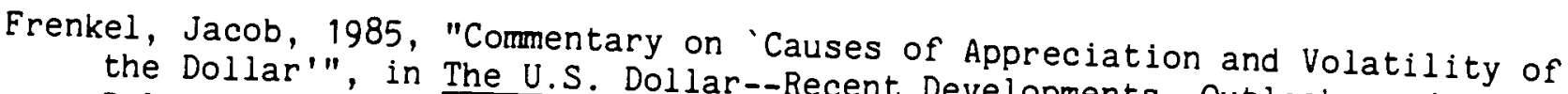
the Dollar'", in The U.S. Dollar--Recent Developments, Outlook, and Policy Options, Kansas City: Federal Reserve Bank of Kansas City, 53-63.

Frenkel, Jacob, and Michael Mussa, 1980, "The efficiency of foreign exchange markets and measures of turbulence," American Economic Review, 70: $374-$

Frenkel, Jacob, and Michael Mussa, 1984, "Asset markets, exchange rates, and the balance of payments," in Ronald W. Jones and Peter B. Kenen, eds., Handbook of International Economics, Vol II, Amsterdam: North-Holland,

Giavazzi, Francesco, and Alberto Giovannini, 1986, "The EMS and the dollar,"
Economic Policy, 1,2: 455-74.

Girton, Lance, and Dale W. Henderson, "Central bank operations in foreign and domestic assets under fixed and flexible exchange rates," in Peter B. Exchange Rate Adjustments. Washington. Sweeney, eds., The Effects of 79. Washington: Department of the Treasury, $151-$

Goldstein, Morris, 1984, The Exchange Rate System: Lessons of the Past and Options for the Future, Occasional Paper No. 30. Washington: International Monetary Fund.

Greene, Margaret L., "U.S. experience with foreign exchange intervention: September 1977-December 1979," Staff Studies No. 128, October. Washington: Board of Governors of the Federal Reserve System.

Hamada, Koichi, and Akiyoshi Horiuchi, 1986, "Monetary and real effects of the internationalization of a national currency: the case of the yen," in Sven Arndt and $J$. David Richardson, eds., Real-Financial Linkages in Open Economies. Washington: American Enterprise Institute, forthcoming.

Hansen, Lars Peter, and Robert J. Hodrick, 1980, "Forward exchange rates as optimal predictors of future spot rates: an econometric analysis," Journal of Political Economy, 88,5 (October): 829-53.

Hansen, Lars Peter, and Robert J. Hodrick, 1983, "Risk averse speculation in the forward foreign exchange market: An econometric analysis of linear Frenkel. Chicago: University of Chicago Press.

Harrod, R. F., 1951, The Life of John Maynard Keynes, London: MacMillan.

Hause, J. C., 1966, "The welfare costs of disequilibrium exchange rates," Journal of Political Economy, 74: (August).

Henderson, Dale W., 1984, "Exchange market intervention operations: Their role in financial policy and their effects," in John Bilson and Richard Marston, eds., Exchange Rate Theory and Practice. Chicago: University
of Chicago Press, 359-443. 
Herring, Richard J., and Richard C. Marston, 1976, "The forward market and interest rates in the Eurocurrency and national money markets," in Carl H. Stem, John H. Makin, and Dennis E. Logue, eds., Eurocurrencies and the International Monetary System, 139-63.

Herring, Richard J., and Richard C. Marston, 1977, National Monetary Policies and International Financial Markets. Amsterdam: North-Holland.

Hooper, Peter, and Steven W. Kohlhagen, 1978, "The effect of exchange rate uncertainty on the prices and volume of international trade," Journal of International Economics, 8, November, 483-511.

Huang, Roger D., 1981, "The monetary approach to the exchange rate in an efficient foreign exchange market: tests based on volatility," Journal of Finance, 36,1 (March): 31-41.

Johnson, Harry G., 1966, "The welfare costs of exchange rate stabilization," Journal of Political Economy, 74: 4.

Kenen, Peter B., 1986, "Exchange-rate management: What role for intervention," paper presented at the A.E.A. meetings, December 1986, processed.

Kenen, Peter B., and Dani Rodrik, 1984, "Measuring and analyzing the effects of short-term volatility in real exchange rates," Working Papers in International Economics, Princeton: International Finance Section, March.

Kouri, Pentti, and Michael Porter, 1974, "International capital flows and portfolio equilibrium," Journal of Political Economy, 82, (May/June): 443-67.

Krause, Lawrence B., 1986, "Does a yen valued at 100 per dollar make any sense?" processed.

Krugman, Paul R., "Is the strong dollar sustainable?" in The U.S. Dollar--Recent Developments, Outlook, and Policy Options, Kansas City: Eederal Reserve Bank of Kansas City, 103-132.

Lanyi, Anthony, and Esther C. Suss, 1982, "Exchange rate variability: alternative measures and interpretation," International Monetary Fund, Staff Papers, December.

Levich, Richard M., 1985, "Empirical studies of exchange rates: price behavior, rate determination and market efficiency," in $R$. W. Jones and P. B. Kenen, eds., Handbook of International Economics, Vol. 2. Amsterdam: North-Holland, 979-1040.

Liviatan, N., 1980, "Anti-inflationary monetary policy and the capital-import tax," Warwick Economic Research Papers 171.

Loopesko, Bonnie E., 1984, "Relationships among Exchange Rates, Intervention, and Interest Rates: An Empirical Investigation," Journal of International Money and Finance, 3,3 (December): 257-77. 
Marston, Richard C., 1984, "Financial disturbances and the effects of an Under Uncertainty. Cambridge: MIT Press.

Marston, Richard $C$,

Ronald W. Jones and Peter "Stabation policies in open economies," in

Economics, Vol 2. Amsterdam: North Holland, 859-916.

United States and Japan" Real exchange rates and productivity growth in the

McKinnon, Ronald I. 1974, A Norking Paper No. 1922, May.

Dollar Standard, Essays in International Finance Agreement or a Limping

International Finance Section.

Meese, Richard A., and Kenneth Rogoff,

of the seventies: Do they fit out 1983, "Empirical exchange rate models Economics, 14, (February): 3-24.

Mussa, Michael, 1979, "Empirical Regularities in the Behavior of Exchange
Rates and Theories of the Foreign Exchange Market," in Karl Brunner and
Allan H. Meltzer, Policies for Employment. Prices, and Exhand
Carnegie-Rochester Carnegie-Rochester Conference Series on Public Policy, Vochange Rates,
57 .

Mussa, Michael, 1981, The Role of Official Intervention, Occasional Papers No.
6. New York: Group of Thirty. Obstfeld, Maurice, 1983, "Exchange rates, inflation, and the sterilization
problem: Germany, 1975-81," European Economic Review, $21,1 / 2$
(March/April): 161-89.

Obstfeld, Maurice, 1985, "Floating Exchange Rates: Experience and Prospects," Brookings Papers on Economic Activity, 2: 369-450.

Padoa-Schioppa, Tomasso, 1985, "Lessons from the European Monetary System," European University Institute "European Forum" Lecture, Firenze: Badia
Fiesolana, February 20th.

Paris, James Daniel, 1938, Monetary Policies of the United States: $1932-38$.
New York: Columbia University Press.

Richardson, J. David, 1984, "The new nexus among trade, industrial and

exchange-rate policies," in Tamir Agmon, Roberte, Industrial and

M. Levich, eds., The Future of the International Howkins, and Richard

Lexington: Lexington Books, 253-79.

Rogoff, Kenneth, 1984, "On the effects of sterilized intervention: an analysis 50 . 
Rogoff, Kenneth, 1985, "Can exchange rate predictability be achieved without monetary convergence: evidence from the EMS," European Economic Review, 28,1-2 (June-July): 93-115.

Shiller, Robert J., 1979, "The volatility of long-term interest rates and expectations models of the term structure," Journal of Political Economy, 87 (December): 1190-1219.

Solomon, Robert, 1977, The International Monetary System, 1945-76: An Insider's View. New York: Harper and Row.

Stulz, Rene, 1981, "A model of international asset pricing," Journal of Financial Economics, 9: 383-406.

Tobin, James, 1982, "A proposal for international monetary reform," in Essays in Economics: Theory and Policy. Cambridge: MIT Press, 488-94.

Ueda, Kazuo, "Japan-U.S. current accounts and exchange rates before and after the G5 agreement," New York University Working Paper No. 15.

Ungerer, Horst, Owen Evans and Peter Nyberg, 1983, The European Monetary System: the Experience, 1979-82, Occasional Paper No. 19, Washington, D.C.: International Monetary Fund, May

Williamson, John, 1985, The Exchange Rate System, Policy Analyses in International Economics No. 5, Washington: Institute for International Economics, June.

Working Group on Foreign Exchange Intervention, 1983, Report. Washington: U.S. Treasury. (In text, referred to as the Jurgensen Report).

Ypersele, Jacques van, 1985, The European Monetary System: Origins, Operation and Outlook, Brussels: Commission of the European Communities. 